\title{
A arte de conjugar tempo e espaço: Fernand Braudel, a geo-história e a longa duração
}

\author{
The art of uniting time and space: Fernand Braudel, \\ geohistory and the long run
}

\section{Guilherme Ribeiro}

Professor, Laboratório de Política, Epistemologia e História da Geografia/Departamento de Geociências/Universidade Federal Rural do Rio de Janeiro.

BR 465, Km 7

23890-000 - Seropédica - RJ - Brasil geofilos@ig.com.br
RIBEIRO, Guilherme. A arte de conjugar tempo e espaço: Fernand Braudel, a geo-história e a longa duração. História, Ciências, Saúde - Manguinhos, Rio de Janeiro, v.22, n.2, abr.jun. 2015, p.605-639.

\section{Resumo}

Apresenta o surgimento do conceito de geo-história, elaborado pelo historiador francês Fernand Braudel no texto "Géohistoire: la société, l'espace et le temps" durante sua prisão pelos alemães em meio à Segunda Guerra Mundial. Tal conceito expressa a crítica de Braudel às fronteiras disciplinares, bem como a relevância da geografia na construção de seu método histórico de longa duração. Duplamente inspirada pelo estudo das relações entre sociedade e meio ambiente oriundo dos geógrafos franceses e pelo trinômio espaço-economia-sociedade proveniente dos geógrafos alemães, a geo-história braudeliana revela uma abordagem muito mais consistente e complexa que as teses de Lucien Febvre contidas no difundido A terra e a evolução humana: introdução geográfica à história.

Palavras-chave: geo-história; Fernand Braudel (1902-1985); Lucien Febvre (1878-1956); geografia francesa; geografia alemã.

\section{Abstract}

This article presents the concept of geohistory, as developed by the French historian Fernand Braudel in his text "Géohistoire: la société, l'espace et le temps", written while he was imprisoned during the Second World War. The concept expresses his criticism of the boundaries of academic disciplines, and the importance of geography in the construction of his long-term history. Inspired both by the study of relations between society and environment based on the work of French geographers, and by the triangular link of space-economysociety of German geographers, Braudel's geohistory presents an approach more consistent and more complex than Lucien Febvre's theses found in The earth and human evolution: e geographical introduction to history.

Keywords: geohistory; Fernand Braudel (1902-1985); Lucien Febvre (18781956); French geography; German geography. 
A tradução que temos a honra de apresentar ao público de língua portuguesa integra um dos capítulos mais bonitos e dramáticos das ciências humanas no século XX. Trata-se das origens e da natureza do conceito de "geo-história", formulado pelo historiador francês Fernand Braudel (1902-1985) entre 1940 e 1945 em um contexto altamente perturbador: obrigado a contribuir nos esforços de guerra, Braudel é capturado pelos alemães, e escreve sobre esse e outros temas durante a prisão. Na medida do possível, as duras condições a que fora submetido eram mitigadas pelo fato de que os Oflags, campos de prisioneiros destinados aos oficiais, estavam resguardados pela Convenção de Genebra, o que lhes dava direito a livros e correspondências - além de lhes impedir a realização de trabalhos forçados.

Assim, Braudel redigiu no cativeiro parte de sua célebre tese de doutorado, defendida na Sorbonne em 1947 e publicada em 1949 pela Armand Colin, La Méditerranée et le monde méditerranéen à l'époque de Philippe II, auxiliado pelo orientador e amigo Lucien Febvre (cofundador dos Annales d'histoire économique et sociale ao lado de Marc Bloch em 1929), que lhe enviava livros, notícias e sugestões. Braudel tinha acesso às bibliotecas dos Oflags, organizava conferências e chegou a ser "reitor" da "universidade" do campo em Mayence posteriormente, ele é transferido para Lübeck em 1942 (Paris, 1999). Dessa época, porém, três belíssimos artigos reveladores da formação de suas ideias só vieram a público mais de cinquenta anos depois: "Trois définitions: l'événement, le hasard, le social" (Braudel, 1997d); "L'histoire à la recherche du monde" (Braudel, 1997c); e "Géohistoire: la société, l'espace et le temps" (Braudel, 1997a) - os três foram escritos entre 1941 e 1944. Junto com outros textos, eles foram organizados e publicados por Roselyne de Ayala e Paule Braudel (viúva do historiador), com prefácio de Maurice Aymard, sob o título Les ambitions de l'histoire (Braudel, 1997b).

Braudel possui interesse pela geografia desde pelo menos sua época de estudante na Sorbonne dos anos 1920, quando os trabalhos de campo ao ar livre interpelando as paisagens promovidos pelos geógrafos pareciam mais atraentes que os empoeirados depósitos de arquivos. A originalidade e o dinamismo da abordagem geográfica ao redor do meio ambiente e da cultura contrastavam com o tratamento factual e simplista conferido às fontes históricas. Portanto, não é coincidência que a escola francesa de geografia esteja na origem da renovação historiográfica perpetrada pelos Annales: incorporar o espaço significava, para dizer o mínimo, ampliar os domínios da história. No caso específico de Braudel, nossa tese é que a geografia possui papel epistemológico central na elaboração de seu pensamento, uma vez que ela está diretamente ligada à apreensão das estruturas de longa duração inscritas na natureza, nas civilizações, nas formações territoriais e nas paisagens materiais (Ribeiro, 2008). Refletir sobre o espaço foi um dos caminhos que lhe permitiram engendrar uma nova concepção de temporalidade, por meio da qual a história passava a ser apreendida segundo três diferentes ritmos: "eventos", "conjunturas" e "estruturas" (Braudel, 1949).

Historiador de formação, porém consagrado como geógrafo, essa maneira de pensar o tempo já estava virtualmente presente na obra de um dos maiores expoentes da geografia francesa contemporânea: Paul Vidal de la Blache (1845-1918). Tal como se observa na obra La France: tableau géographique - escrita originalmente em 1903 - e no artigo "Les pays de France" (Vidal de la Blache, 2007, 1904, p.343), o exame das relações entre sociedade, meio ambiente e território na constituição da França demandava uma leitura ampliada do processo histórico. Atuando como uma espécie de coerção à perspectiva teleológica em voga no século 
XIX, entravam em cena o pays, o solo, a região. As "camadas do espaço" interrogariam profundamente a cronologia, e Braudel foi um dos que perceberam isso de maneira mais perspicaz.

Em uma passagem que guarda visível semelhança (até do ponto de vista textual) com a reflexão braudeliana sobre o tempo, Vidal de la Blache (2007, p.783) registrou:

Revoluções econômicas como as que se desenvolvem atualmente imprimem extraordinária agitação na alma humana; movimentam uma gama de desejos, de novas ambições. Em alguns, inspiram arrependimentos; em outros, fantasias. Entretanto, essa inquietação não deve nos desviar do fundamento das coisas. Quando um golpe de vento agita violentamente uma superfície de água muito límpida, tudo oscila e se mistura; porém, em um instante, a imagem do fundo é novamente desenhada. O estudo atento do que é fixo e permanente nas condições geográficas da França deve ser ou deve tornar-se, mais que nunca, nosso guia.

Assim, a contribuição de Vidal de la Blache foi basilar para que Braudel pensasse as estruturas da história, os movimentos lentos que demoravam a passar (Ribeiro, 2014). Entretanto, isso não o impediu de reconhecer as mudanças. Eis aqui um grande desvio interpretativo cometido por alguns (Guriêvitch, 2003), pois para Braudel (2002, p.335) a geografia não era apenas sinônimo de permanências, nem tampouco sua história interessava-se exclusivamente pelas estruturas. Conforme apontamos em outra ocasião (Ribeiro, 2011a), não concordamos com leituras que sugerem que Braudel "colonizou" (Santos, 2002, p.266) e "encerrou" a geografia na longa duração (Ozouf-Marignier, Robic, 2000, p.268), com a geo-história limitando-se a ser um "operador do tempo imóvel" (Dosse, 2004, p.127).

Ótimo exemplo para contestar tais discursos é a trilogia Civilização material, economia e capitalismo: séculos XV-XVIII: as estruturas do cotidiano (v.1); Os jogos das trocas (v.2); e O tempo do mundo (v.3) (Braudel, 1996a, 1996b, 1996c), investigação profunda e refinada sobre as modificações sociais, políticas, culturais e, sobretudo, econômicas que caracterizaram o mundo moderno. Em termos geo-históricos, cumpre separar suas interpretações sobre a multissecular passagem de um mundo agrário e camponês para um mundo urbano e industrial, deixando para trás o "antigo regime biológico"; a decadência das cidades-Estado (Stadtwirtschaft) em proveito dos Estados territoriais (Territorialwirtschaft); e a conformação do capitalismo como um sistema verdadeiramente mundial, cujos principais atores lançam suas redes das escalas local à global, operam em vários setores da atividade econômica e são oligopolistas por natureza.

Portanto, se no concerto das ciências humanas a geografia acabou, de algum modo, subordinada à história, Braudel está longe de ser um dos responsáveis. A situação é exatamente oposta em "Géohistoire: la société, l'espace et le temps" (Braudel, 1997a). Ao mesmo tempo que recomenda aos geógrafos franceses não abrir mão do papel do ambiente, diz que, para a compreensão desse ambiente, é necessário partir da sociedade, e não o inverso - recuperando, inclusive, as contribuições da sociologia de Marcel Mauss e Maurice Halbwachs. Ademais, ao considerar as relações homem-meio sob o prisma estrutural e reconhecer que um dos principais capítulos da história moderna diz respeito à conquista da superfície terrestre, Braudel confere à geografia papel central na constituição da Modernidade.

Além da escola francesa de geografia, Braudel lançou mão de outra matriz para compor sua geo-história: a tradição alemã e seus conceitos de "espaço" (Raum), "economia" (Wirtschaft) e "sociedade" (Gesellschaft) (Ribeiro, 2012). Se com seus compatriotas Braudel explora a 
"dimensão estrutural" do meio ambiente no desenvolvimento da vida social, com os aportes dos alemães ele investiga a "valorização total do espaço", incorporando temas como o papel das cidades, as escalas da economia, as políticas de formação territorial dos Estados, as economias-mundo (Weltwirtschaften) (Ribeiro, 2011b, 2011c). Em outras palavras, é essencial ressaltar que a geo-história braudeliana não se restringe aos franceses e nem tampouco a La Méditerranée et le monde méditerranéen à l'époque de Philippe II: ela foi idealizada antes deste e, principalmente, está presente na totalidade de sua obra. A história de longa duração é, por inteiro, geo-história: do meio ambiente, das paisagens culturais, dos territórios nacionais, da expansão do capitalismo (Braudel, 1969, 1989a, 1989b, 1989c, 1996a, 1996b, 1996c). Dissociá-las significa alcançar apenas parcialmente a démarche e as conclusões braudelianas.

Dito isso, cabe perguntar: quais razões o levaram a criar a "geo-história"? A resposta está na sua percepção da existência de uma dupla crise: a geografia vivia a crise da "descrição", enquanto a história sofria a crise da "narração". Quer dizer: ambas lhe pareciam pouco analíticas e, no limite, ingênuas, diante da tarefa de explicar os fenômenos. Consoante sua postura de questionar as fronteiras disciplinares e ampliar o diálogo entre as ciências, Braudel quis problematizá-las "em conjunto", e não isoladamente, o que nos parece iniciativa verdadeiramente pioneira - e, até nossos dias, sem concorrentes.

No entanto, como era típico de sua inquietude intelectual, ele via limites em ambas as matrizes: enquanto os franceses precisavam investir mais no estudo da "sociedade", os alemães grifavam em excesso a relevância do "Estado". Assim, sua geo-história não é apenas a fusão de duas tradições, mas seu aperfeiçoamento em uma tessitura cuidadosamente equilibrada. Trata-se de ferramenta capaz de perscrutar como o meio ambiente e o espaço construído integraram o processo histórico de longa duração que transformou a superfície terrestre em ecúmeno - o que significa escavar seus efeitos na composição da vida social.

Braudel não aparta sociedade e espaço: a história não acontece primeiro para, no momento seguinte, deparar-se com o espaço. Sua lição para as ciências humanas versa que a história das sociedades é simultaneamente temporal e espacial e que o espaço, embora alterado, apresentase como uma estrutura da história. É dos laços entre as sociedades e seus espaços que Braudel apreende os diferentes ritmos da história. Em outras palavras, uma mudança de escala pode ser também uma mudança de temporalidade. Por isso sua geo-história é multiescalar, pois espaço é sinônimo de diversidade, de conexão, de redes entrelaçadas - noções que põem em xeque o tempo linear e as filosofias do progresso.

As considerações expostas até aqui restariam incompletas se não destacassem o notório descompasso entre a "geografia humana modesta" proposta por Lucien Febvre (1991) em 1922 no célebre A terra e a evolução humana: introdução geográfica à história e a complexa perspectiva geo-histórica de Fernand Braudel a partir dos anos 1940. Com Febvre, estamos diante de uma apropriação utilitarista da geografia, que a restringe aos estudos dos elementos físicos e forja uma oposição que jamais existiu entre o "possibilismo" de Vidal de la Blache e o "determinismo" de Ratzel - tudo em nome de rivalidades nacionalistas e de um projeto intelectual que situava a história no cerne das ciências humanas (Ribeiro, 2009). Para Braudel, a geografia permite a ampliação do próprio campo histórico: sua "história total" incorporaria, necessariamente, a trama envolvendo a distância, a natureza e o território. A emergência da história mundial (Weltgeschichte) representou, de forma incontornável, a luta humana contra 
ambientes inóspitos que, com auxílio imprescindível da técnica, foram transformados em espaços aptos ao desenvolvimento econômico e político das sociedades modernas.

Destarte, a geo-história encarna - avant la lettre, de certa forma - a produção geográfica do século XX, pois essa, gradualmente, "humaniza" o espaço ao abordá-lo em termos políticoeconômicos, ao mesmo tempo que, mesmo diante das profundas intervenções humanas sobre o meio, preserva a indissociabilidade das sociedades em relação a ele. Além do mais, do ponto de vista epistemológico, a reflexão braudeliana, ao recusar a dicotomia homem-meio e interrogar as barreiras disciplinares, representa uma crítica à ciência moderna antes mesmo da emergência do pós-estruturalismo nos anos 1960 e 1970.

Todavia, por mais surpreendente que possa parecer, as ideias de Febvre continuam a "referendar" a aproximação entre geógrafos e historiadores, ao passo que a geo-história permanece deslocada e secundária. Mesmo sendo o intelectual que mais dialogou com a geografia no século passado, Fernand Braudel despertou pouco interesse dos geógrafos.

O que pode explicar tal situação? A título de hipótese, aventemos três motivos: primeiro, a excessiva proeminência do tempo presente na análise geográfica (crítica, aliás, identificada pelo próprio Braudel na tradução a seguir). Sobretudo a partir de 1945, os geógrafos manifestam cada vez menos apreço por uma discussão sobre o tempo, sobre a articulação presente-passado, sobre processos históricos. Em segundo lugar, tanto a escola francesa de geografia quanto a geografia alemã recebem inúmeras, porém perniciosas, críticas: apropriando-se apenas de uma ou outra obra sem uma reflexão mais elaborada e descontextualizada da conjuntura histórico-social, autores de notória riqueza como Carl Ritter, Friedrich Ratzel, Paul Vidal de la Blache e Albert Demangeon foram tidos como ultrapassados. Rótulos como "descritivismo", "empirismo" e "regionalismo" foram suficientes para que toda uma geração os deixasse de lado; e, uma vez que o diálogo mais profícuo de Braudel deu-se majoritariamente com os geógrafos de sua geração, sua própria geo-história soou como algo igualmente fora de moda. Em terceiro lugar, a hegemonia dos geógrafos marxistas entre o final dos anos 1970 e os anos 1990, amparados pela fértil teorização do filósofo francês Henri Lefebvre acerca da produção do espaço e da urbanização completa da sociedade (Lefebvre, 2000, 2008), também pode ter cooperado para deslocar o pensamento de Braudel - uma pena, dadas as inúmeras convergências entre ambos no tocante aos vínculos entre espaço e história.

Ao término dessa apresentação, destacamos que seria de grande valia retomar o legado de Fernand Braudel, inclusive para objetá-lo com o devido rigor que sua obra merece, pois, embora tenha inspirado intelectuais da estatura de Immanuel Wallerstein (1974) e Giovanni Arrighi (1996), algumas de suas posições políticas conservadoras sobre o capitalismo, o colonialismo e a nação franceses (ver Braudel, 1989a, 1989b, 1989c; ver também Ribeiro, 2010) possivelmente serviram para que alguns dos melhores representantes do pensamento crítico dele se afastassem, ao mesmo tempo que o simples fato de não comungar com o marxismo fez dele alvo de julgamentos superficiais (vide Fontana, 1998, p.208-210).

Talvez seja o caso de relê-lo para além das polarizações da Guerra Fria. Afinal, conceitos como "geo-história", "longa duração" e "história total", além de sua interpretação sobre os três andares da vida econômica, ainda possuem muito a dizer sobre a Modernidade e, por conseguinte, sobre nossos dias. Em uma palavra: o método braudeliano ainda é capaz de fertilizar as ciências humanas (ver Aguirre Rojas, 2003). Em tempos de câmbio epistemológico, 
sua obra ressalta a dimensão incontornável do processo histórico no entendimento de todo e qualquer fenômeno social, atenta para o espaço, a fim de compreender a diversidade do mundo, e propõe ampla cooperação entre as ciências.

A menção a esses aspectos já é suficiente para deduzir seu impacto: trata-se de um duplo antídoto contra o fim da história e o fim da geografia preconizado por alguns (Fukuyama, 1992; Virilio, 1993). No instante em que a Weltgeschichte é uma realidade empírica nos quatro cantos do planeta, que dizer da análise global levada a cabo por Braudel? No momento em que precisamos decifrar, talvez mais que nunca, como o mundo tornou-se essa realidade tangível na qual estamos atualmente imersos, a obra de Braudel nos impele a considerar esse mesmo mundo escala primeira e incontornável de referência.

Enfim, Braudel escreveu a história dos espaços. Basta conhecer um pouco da trajetória das ciências humanas para saber o quanto tal projeto foi ignorado - e, por essa mesma razão, o quanto ele continua essencial.

\section{AGRADECIMENTOS}

Em sua fase inicial, a pesquisa que originou este texto contou com o apoio da Capes e, nos últimos anos, com os auxílios da Faperj e da UFRRJ.

\section{REFERÊNCIAS}

ARRIGHI, Giovanni.

O longo século $X X$ : dinheiro, poder e as origens do nosso tempo. Rio de Janeiro: Contraponto; São Paulo: Unesp. 1996.

AGUIRRE ROJAS, Carlos Antonio.

Fernand Braudel e as ciências humanas. Londrina: Eduem. 2003.

BRAUDEL, Fernand.

El Mediterráneo y el mundo mediterráneo en la época de Felipe II. t.1. México, D.F.: Fondo de Cultura Económica. 2002.

BRAUDEL, Fernand.

Géohistoire: la société, l'espace et le temps. In: Braudel, Fernand. Les ambitions de l'histoire. Édition établie et présentée par Roselyne de Ayala e Paule Braudel. Paris: Éditions de Fallois. p.68-114. 1997a.

BRAUDEL, Fernand.

Les ambitions de l'histoire. Édition établie et présentée par Roselyne de Ayala e Paule Braudel. Paris: Éditions de Fallois. 1997b.

BRAUDEL, Fernand.

L'histoire à la recherche de monde. In: Braudel, Fernand. Les ambitions de l'histoire. Édition établie et présentée par Roselyne de Ayala e Paule Braudel. Paris: Éditions de Fallois. p.51-67. 1997c.

BRAUDEL, Fernand.

Trois définitions: l'événement, le hasard, le social. In: Braudel, Fernand. Les ambitions de l'histoire. Édition établie et présentée par Roselyne de Ayala e Paule Braudel. Paris: Éditions de Fallois. p.27-50. 1997d.

BRAUDEL, Fernand.

Civilização material, economia e capitalismo:

séculos XV-XVIII. v.1: as estruturas do cotidiano. São Paulo: Martins Fontes. 1996a.

BRAUDEL, Fernand.

Civilização material, economia e capitalismo: séculos XV-XVIII. v.2: os jogos das trocas. São Paulo: Martins Fontes. 1996b.

BRAUDEL, Fernand.

Civilização material, economia e capitalismo: séculos XV-XVIII. v.3: o tempo do mundo. São Paulo: Martins Fontes. 1996c.

BRAUDEL, Fernand.

A identidade da França: o espaço e a história. v.1. São Paulo: Globo. 1989a.

BRAUDEL, Fernand.

A identidade da França: os homens e as coisas. v.2. São Paulo: Globo. 1989b.

BRAUDEL, Fernand.

A identidade da França: os homens e as coisas. v.3. São Paulo: Globo. 1989c.

BRAUDEL, Fernand.

Écrits sur l'histoire. Paris: Flammarion. 1969. 
BRAUDEL, Fernand.

La Méditerranée et le monde méditerranéen à

l'époque de Philippe II. Paris: Armand Colin. 1949.

DOSSE, François.

O recurso geográfico dos historiadores. In: Dosse, François. História e ciências sociais. Bauru: Edusc. p.115-148. 2004.

FEBVRE, Lucien.

A terra e a evolução humana: introdução geográfica à história. Lisboa: Cosmos. 1991.

FONTANA, Josef.

História: análise do passado e projeto social.

Bauru: Edusc. 1998.

FUKUYAMA, Francis.

O fim da história e o último homem. Rio de Janeiro: Rocco. 1992.

GURIÊVITCH, Aaron.

A sintese histórica e a escola dos anais. São Paulo: Perspectiva. 2003.

LEFEBVRE, Henri.

A revolução urbana. Belo Horizonte: Editora da UFMG. 2008.

LEFEBVRE, Henri.

La production de l'espace. Paris: Anthropos. 2000.

OZOUF-MARIGNIER, Marie-Vic; ROBIC, MarieClaire.

Un Tableau à vif... La réception du Tableau de la géographie de la France de P. Vidal de la Blache. In: Robic, Marie-Claire (Dir.). Le Tableau de la Géographie de la France de Paul Vidal de la Blache: dans le labyrinthe des formes. Paris: Éditions du CTHS. p.251-270. 2000.

PARIS, Erato.

La genèse intellectuelle de l'oeuvre de Fernand Braudel. Athènes: Institute de Recherches Néohelléniques/FNRS. 1999.

RIBEIRO, Guilherme.

Question régionale, identité nationale et l'émergence du monde urbain-industriel: la modernité dans l'œuvre de Paul Vidal de la Blache. Annales de Géographie, v.699, p.12151238. 2014.

RIBEIRO, Guilherme.

La genèse de la géohistoire chez Fernand Braudel: un chapitre braudelien de l'histoire de la pensée géographique. Annales de Géographie, v.686, p.329-346. 2012.
RIBEIRO, Guilherme.

Fernand Braudel e a geo-história das civilizações. História, Ciências, Saúde-Manguinhos, v.18, n.1, p.67-83. 2011a.

RIBEIRO, Guilherme.

Espaço e técnica como estruturas do cotidiano: capítulos braudelianos de história do pensamento geográfico. Investigaciones Geográficas, Boletín del Instituto de Geografía, UNAM, n.74, p.58-73. 2011b.

RIBEIRO, Guilherme.

A valorização total do espaço: capitalismo e geografia em Civilisation matérielle, économie e capitalisme: XV-XVII siècles. Estudos Históricos, v.24, n.47, p.5-27. 2011c.

RIBEIRO, Guilherme.

A geografia na formação do território francês: capítulos braudelianos de história do pensamento geográfico. Confins, v.10, n.10, p.120. 2010.

RIBEIRO, Guilherme.

Para ler geografia ou a geografia segundo Lucien Febvre. Terra Livre, v.1, n.32, p.121-136. 2009.

RIBEIRO, Guilherme.

Espaço, tempo e epistemologia no século XX: a geografia na obra de Fernand Braudel. Tese (Doutorado em Geografia) - Universidade Federal Fluminense, Niterói. 2008.

SANTOS, Milton.

A natureza do espaço: técnica e tempo - razão e emoção. São Paulo: Hucitec. 2002.

VIDAL DE LA BLACHE, Paul.

La France: tableau géographique. In: Rioux, JeanPierre. Tableaux de la France: Michelet, Duruy, Vidal de la Blache et Bruno. Paris: Omnibus. p.327-783. 2007.

VIDAL DE LA BLACHE, Paul.

Les pays de France. La réforme sociale, v.48, n.8, p.333-344. 1904.

VIRILIO, Paul.

O espaço crítico. São Paulo: Editora 34. 1993.

WALLERSTEIN, Immanuel.

The modern world-system: capitalist agriculture and the origins of the european world-economy in the sixteenth century. New York: Academic Press. 1974. 


\title{
Geo-história: a sociedade, o espaço e o tempo*
}

\author{
Fernand Braudel
}

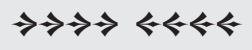

"O espaço é mais importante que o tempo" (Karl Haushofer)

"Sob a superficial agitação dos eventos, circula nas profundezas a grande corrente apática que nos move sem alarme e sem indiferença. Antes de tudo, somos os fluxos desse movimento, os instantes desse impossível percurso do qual somos, apenas, a argila da terra..." (Gaston Roupnel, Histoire et destin, 1943)

\section{A geografia, ciência inacabada}

\footnotetext{
"A geografia não se limita ao estudo da Terra; ela se estende a tudo o que vive sobre a Terra - notadamente o homem, sua vida econômica, social e política" (André Siegfried, Cours de Géographie Humaine, 1941).
}

"Renunciemos a considerar os homens como indivíduos" (Albert Demangeon, Problèmes de Géographie Humaine, 1942).

Os geógrafos bem o sabem: a despeito do dinamismo de seu ensino - essa revolução do presente -, da quantidade e da qualidade de trabalhos realizados (teses, livros, revistas, coleções, atlas, manuais escolares) e da excelência dos métodos que ela seguiu, a geografia é uma ciência inacabada. Independente de todas as suas riquezas, a geografia é, mesmo, terrivelmente inacabada. Como todas as ciências do homem? Sim, é claro... Porém, mais ainda que essas outras ciências, visto que mais complicada e, com exceção da história, ${ }^{1}$ bem mais antiga que todas elas. De fato, a geografia é uma aventura intelectual muito antiga que, por suas origens, se confunde com os primeiros passos deliberados do pensamento e da reflexão humanos. Ainda que se diga, ela não começou com Humboldt, Ritter, Ratzel ou, entre os franceses, Vidal de la Blache. Heródoto não é apenas o pai da história, mas também da geografia, dessa geografia tão modificada desde então e tão parecida consigo mesma; rica de experiências e de tarefas apaixonantes, mas numerosas; geralmente perturbada por suas tradições; envolvida em vários falsos problemas e, ainda, complicada por suas poderosas aquisições recentes. No decorrer dos últimos cinquenta anos, a geografia ampliou muito e rapidamente o domínio de seu trabalho horizontal às custas dos territórios de outras ciências mais das ciências da natureza que das do homem -, e, como se sabe, todo imperialismo sobrecarrega. Existe mesmo, nas ciências do homem, domínio cujas realidades são mais vastas e mais heteróclitas que as da geografia? 
Eis por que, na atualidade, a geografia nem sempre parece suficientemente livre em seus movimentos, suficientemente flexível para voltar-se de modo deliberado em direção ao real; ou, o que vem a ser quase a mesma coisa, para definir-se com solidez, para escolher entre suas tarefas possíveis e classificá-las segundo seu grau de importância em relação ao homem. Há uma crise da geografia. Percebê-la é esclarecer nossa própria crise da história.

$\mathrm{O}$ argumento vale tanto para a geografia quanto para a história: em vez de sempre as servir, o passado as oprime ou, ao menos, as incomoda. Em 1942 (veja o precioso Guide de André Cholley), ${ }^{2}$ a geografia ainda se apresenta como a descrição da Terra. Inicialmente, coisa da etimologia, não é verdade? Tal como a história, que, em 1942, como dissemos, ${ }^{3}$ também sempre se apresenta como uma narrativa, uma ciência do acontecimento - porém, sem estar consciente disto, o que agrava seu caso. Os resultados são os mesmos: de um lado, os eventos, as peripécias, os gestos dos grandes ou pretensos grandes homens, toda uma história de superfície; do outro lado, simetricamente, as descrições, as viagens, toda uma geografia também de superfície. De uma parte, a arte do narrador; de outra, obrigatoriamente, as notas, as memórias do viajante e, hoje, mais prestigiadas ainda, as do explorador.

Reconheçamos que, nesses domínios, muito frequentemente estamos longe da ciência com C maiúsculo. Descrever é ver o particular, capturar a vida, e, na verdade, é bem isso o que o público demanda, pois, para ele, história e geografia permanecem meios conhecidos e testados de aventura e de evasão fora da monotonia da vida habitual, caminhos de exílio e de sonho. Nada de muito frequente, mas o suficiente. Eis, ao alcance da mão de quem não viaja - e cada um gostaria de viajar -, países que o público não visitará, mas, se quiser, poderá fazê-lo pela imaginação. Evoquemos o desejo do leitor: ver tão perto quanto possível, ter a impressão de estar no lugar. Que tentação a de se preparar, despido de todo véu, para ganhar países estrangeiros e exóticos dos quais cada um de nós é nostálgico. Questão de literatura e de propaganda, questão de época! Para além de todo véu, igualmente é possível alcançar, em uma outra viagem, países do passado... Primeira direção: a literatura das estradas, das estações [gares], dos sleepings e dos steamers. Segunda direção: as vidas romanceadas e as crônicas do passado. Para o historiador e para o geógrafo, a situação é a mesma: no limite de seus respectivos ofícios, é grande a tentação de se fixar nessas atividades básicas, tradicionais, fáceis e plenas de interesse humano. Ser lido e se fazer ler não é agir?

Aliás, descrever é um meio de conhecer; observar, e bem, é a primeira tarefa do geógrafo. Trata-se de matéria inesgotável. Quantas regiões do mundo são mal conhecidas geograficamente! Ademais, quando a descrição está terminando, quase sempre o trabalho está por recomeçar - um pouco antes, um pouco depois, pois as palavras das quais nos servimos para pintar envelhecem muito rápido, assim como nosso equipamento de viagem e de pintura e nossas próprias imagens. É preciso trocá-las, renová-las sem intervalos, da mesma forma que a própria Terra se transforma e os povos evoluem, aos quais é necessário visitar incessantemente. A volta ao mundo em oitenta dias feita por Phileas Fogg é de 1872. Como está fora de moda! Duvido que ainda seja prazeroso para nossas crianças no futuro e mesmo hoje. Vejam bem: o Marrocos de que vocês me falam é o de 1935. Porém, ele não é mais - eu lhes asseguro - o Marrocos de 1942. Bem temo que a América do Sul, que visitei entre 1935 e 1937, não tenha sido dissipada nesse intervalo, modificada terrivelmente em seu âmago por conta dos anos da grande adversidade. Também estou certo de que, observada em 1905, 
a Picardia de Albert Demangeon, ${ }^{5}$ essa Picardia robusta, pujante, bem mergulhada em seus vales, fixada às suas planícies aluviais e aos seus vastos campos de argila, esse mundo rico de valores sólidos, já não se enquadra mais em seu antigo retrato. Pobre e frágil esboço o do mundo vivente! Mal a pintura seca e o modelo deixa de parecer com sua imagem. Descobrir, redescobrir, descrever, reescrever - o trabalho é interminável.

Oriunda dos vigorosos ensinamentos de Vidal de la Blache, a "escola geográfica francesa" não terá recuado diante dessa empreitada. Ela quis, e soube, ver bem. Ela terá alcançado mesmo uma espécie de perfeição na arte de descrever a Terra; perfeição, até onde pude conhecer, jamais igualada no estrangeiro, porém nem sempre assinalada entre nós como conviria. Entretanto, é uma de nossas verdadeiras conquistas literárias! A "escola francesa" soube fazer da descrição uma arte precisa, sóbria, encantadora, de beleza incontestável; uma arte de pintar segundo nossas melhores tradições. No mesmo movimento, ela fez do ofício do geógrafo um trabalho ao ar livre, de viajante, de observador do real, de quase camponês. E esse não é seu menor mérito.

Em seu admirável Tableau de la géographie de la France, ${ }^{6}$ Vidal de la Blache deu o exemplo não o primeiro, claro. O solo, o relevo, os cursos d'água, o céu, a vegetação (tanto em suas linhas quanto em seus volumes), a comovente face humana da França, foram apreendidos por ele com uma inteligência maravilhosa, com uma ternura menos romântica mas que evoca Michelet. Uma descrição densa em anotações curtas, nervosas, de traços nítidos, incisivos e cores límpidas, com aguçado senso da harmonia das combinações. O "todo" 7 com a sobriedade de um clássico: nada de floreios nessa escrita precisa, talvez muito precisa, do mestre! Todos os alunos de Vidal retomaram, a seu modo, essa sugestiva arte da descrição, cada qual adaptando-a a seu próprio temperamento e criando sua escrita, seu estilo. Em sua planície da Picardia, o estilo de Demangeon consiste em planos rapidamente desenvolvidos, com amplas nuanças, de maneira simples. Escritor de grande classe, Jules Sion admite uma forma tão diferente e tão pessoal, com traços precisos, categóricos, enorme clareza. O quadro de Maximilien Sorre em seus Pirineus Orientais ${ }^{8}$ caracteriza-se por traços de cores multiplicadas, finas, porém densas, que invadem as páginas com cores da terra, das plantas, dos maciços florestais, das pradarias, do conjunto das habitações e das vertentes ensolaradas, em que apenas as marcas de sombra me parecem um pouco raras. $\mathrm{O}$ estilo de Emmanuel de Martonne: croquis rapidamente esboçados, expressivos, raramente ornados por cores cruas. O de Émile-Félix Gautier é surpreendente, com quadros, eu diria, "pitorescos", geralmente bastante caricaturais, porém sempre cheios de vida. Gautier é, provavelmente, o maior entre os geógrafos e os historiadores de expressão francesa às vésperas dessa última guerra. ${ }^{9}$ No geral, não creio que a verdadeira literatura habitualmente ofereça o equivalente a essas escritas harmoniosas, inteligentes. Trata-se bem de toda uma arte minuciosa e perspicaz da paisagem. Em suma, uma grande conquista que, às vezes, enfatiza, de modo um pouco cruel, as tentativas de geógrafos menos dotados que seus mestres. Cada escola de pintura não possui seus artistas de segundo escalão?

Trata-se, ainda, de uma forma de descrever - e de descrever melhor - do que de recorrer ao quadro da região natural. Isso volta a decompor um espaço, por si próprio matizado, em pequenos espaços que são, praticamente, da mesma tonalidade, e nos quais os aspectos geográficos são visivelmente os mesmos. É quebrar o vitral para decompô-lo em seus 
fragmentos monocromáticos - partir a dificuldade para melhor compreendê-la. E, novamente, na sequência de Vidal de la Blache e Albert Demangeon, a escola francesa multiplicou suas obras de qualidade. Desde o trabalho clássico de Demangeon consagrado à planície picarda (1905), até a tese, ainda recente porém notável, de Roger Dion sobre o vale do Loire $(1933)^{10}$ (outro trabalho clássico), ela fez maravilhas - principalmente no que concerne ao nosso país.

Precisamos nos repetir? Na literatura geográfica internacional não há nada comparável a esses livros densos, nos quais as imagens de nossas províncias geográficas vivem e são elucidadas. Digamos sem orgulho inútil: existe no mundo país que se dedique tanto quanto a França, com suas províncias e seus pays (terroirs individualizados, ricos de um longo passado e de uma poderosa experiência humana), a tão rico estudo regional? Em países novos, ou menos antigos que o nosso, onde não há homens ligados à terra, fixados, após milênios, aos seus trabalhos, aos seus campos e suas aldeias, onde não abundam, como entre nós, essas "realidades" que são os pays, existe tão bela e influente matéria para a geografia regional? Seguramente, não. Portanto, temos admiráveis imagens da França, e, a partir de seu modelo, esboçadas por nossos geógrafos, admiráveis imagens do mundo. Aliás, todas a serem retomadas - um pouco antes, um pouco depois, visto que é a lei inevitável do gênero.

Descrever. Contudo, resta explicar. A geografia é uma "descrição racional". No decorrer dos últimos cinquenta anos, e mesmo antes, ela afirmou-se como ciência da paisagem. Mais precisamente, um estudo científico do meio natural ou geográfico ou, com mais exatidão ainda, do meio físico e biológico, com tais fórmulas valendo, grosso modo, para designar o environnement da vida humana de que falam os geógrafos americanos. Aliás, é nesse estudo do meio que os progressos mais perceptíveis foram realizados, e Deus sabe com qual dinamismo! Nos anos 1920, certamente não foram os geógrafos da Sorbonne que poderiam ser reprovados pelas pusilanimidades e críticas esterilizantes típicas de seus colegas historiadores. Que diferença! Aqui, Sylvestre Bonnard; lá, ao contrário, vida, céu aberto, amplos problemas humanos... Os geógrafos foram os verdadeiros mestre de nossa juventude. Ao nosso ver, a única reprovação a lhes fazer é, talvez, o fato de terem estado mais perto do físico e de suas certezas que do humano e suas desconcertantes complexidades.

Sabemos que não há manuais perfeitos, escritos de uma vez por todas; porém, existem manuais preciosos e que, com a condição de serem regularmente atualizados, sintetizam todos nossos conhecimentos válidos. Há, assim, para a geografia física, o belo manual alemão de Alfred Philippson. ${ }^{11}$ Em francês, o admirável Traité de geographie physique, de E. de Martonne. Felizes, muito felizes, são os estudantes de geografia, vocês me dirão. Nenhum problema de tectônica, climatologia ou hidrografia lhes parecerá complicado. Estudantes muito afortunados, talvez, visto que bastante inclinados a situar seus passos na rota de seus antecessores. A verdadeira vida intelectual tem o custo dos riscos e das novas dificuldades. Infelizes os intelectuais sem inquietude! Infelizes os discípulos imitadores!

Sob a condição de estar atento, depois que se tratou de colocar o homem em cena e em evidência, as dificuldades verdadeiras, enriquecedoras, felizmente, apareceram - seja indiretamente, quando se trata da geografia econômica, seja diretamente, quando da investida nos vastos e difíceis problemas da geografia humana, ciência a constituir, a delimitar, a afirmar. No que concerne à economia, dispomos de bons trabalhos, ferramentas excelentes e perspectivas teóricas e práticas da economia política que o geógrafo, eu o sei, 
muito habitualmente ignora, mas que estão à disposição. É quando o homem é diretamente abordado, quando se tenta apreendê-lo, que os verdadeiros manuais nos fazem falta. Vidal de la Blache não teve tempo de terminar seu Traité de géographie humaine, do qual foram publicadas, após sua inesperada morte em 1918, as páginas inacabadas, os Principes de géographie humaine (1922). ${ }^{12}$ Notas admiráveis, mas não um livro. A mesma aventura desoladora ocorreu com Demangeon, morto em 1940. De seu Problèmes de géographie humaine $^{13}$ (publicado dois anos após seu falecimento), apenas as dez primeiras páginas são novas. Infelizmente. Formam uma introdução perfeita, nada mais que isso, a uma obra didática pela qual ainda esperaremos por muito tempo. Que essa dupla aventura possa, ao menos, servir de advertência. Esses dois "descobridores" chegaram muito tarde nessas terras tão novas dos problemas imediatos do homem.

Isso não quer dizer que nada tenha sido feito, entre nós ou no estrangeiro, nesse apaixonante domínio. Ao contrário, quantos estudos sobre povoamento, habitação, cidades, movimentos populacionais! Quantas obras excelentes sobre essa ou aquela questão específica! Quantas aquisições ricas, quantos métodos venturosos e pontos de vista engenhosos para cartografar e explicar a movente e complexa substância da geografia dos homens. Nada é também totalmente inútil no livro - eu o quero bem, embora muito descritivo, muito simplista, muito na superfície dos problemas - La géographie humaine, de Jean Brunhes, ${ }^{14}$ que seu discípulo Pierre Deffontaines resume em uma quarta edição viva, alerta, bem atual. Quantas palavras surpreendentes e profundas nesse livro apaixonante, onde tantos problemas foram pressentidos e, com frequência, formulados com exatidão! Para sermos justos com seus pontos de vista, não esqueçamos que é um livro cuja primeira edição data de 1910. Portanto, com seus méritos e imperfeições, é obra de um pioneiro - ainda que em 1942, é preciso dizêlo, nem sempre seja aceitável.

Porém, quão complexo é o objeto da geografia humana! Após tantos outros, repetimos isso somente para não sermos injustos aos olhos de quem já o disse. Por volta de 1890, no início da ciência geográfica - no tempo de Ratzel, verdadeiro fundador da escola geográfica alemã -, e mesmo antes, na época de Taine, era possível supor a existência de uma íntima ligação entre o homem e seu meio. Podia-se acreditar firmemente no determinismo geográfico, tão mais fácil de domá-lo quanto mais grossa sua amarra. Contudo, foi preciso renunciar rapidamente às suas pretensões. Formada um pouco mais tarde, a escola francesa jamais acreditou muito nesse tipo de determinismo. Para Vidal, um ambiente geográfico é um conjunto de possibilidades; cabe ao homem escolher entre eles, tal como grãos que ele poderia ou não semear; cabe ao homem "tomar partido". Eis, em duas palavras, o possibilismo vidaliano. Eis também a tese do brilhante livro de Lucien Febvre La Terre et l'évolution humaine (1924). ${ }^{15}$ Entretanto, ao meu ver, o livro é muito orientado no sentido de acentuar a vontade e a liberdade humanas. De todo modo, trata-se do único livro de método que dispomos sobre essas difíceis questões. Todavia, entre os geógrafos, foi dado a essa obra todo seu profundo significado? Parece que ela foi compreendida apenas como uma advertência, um apelo à prudência, ao "talvez", ao "de acordo com o contexto", aos "sem dúvida" dos espíritos que resistem. No entanto, que não exageremos na lógica da negação do determinismo levada às suas últimas consequências!

Por sua vez, os geógrafos alemães jamais creram nesse "possibilismo", nessas prudências, permanecendo todos fortemente "ratzelianos". Toda a escola geopolítica de Munique deriva 
do pensamento de Ratzel. Porém, a despeito do que tenha sido dito, seu esforço merece nossa consideração. Persistência de Ratzel! Daí a solidez, a simplicidade dos livros e das afirmações dos geógrafos alemães. A complexidade humana os surpreende, ou, antes, os desencoraja muito menos que a nós. Talvez a verdade esteja a meio caminho entre nossas dúvidas e suas audácias [hardiesses]. Os geógrafos alemães me parecem mais “ousados" que nós, mais votados a desenvolver as consequências de uma ideia ou tese, a mostrá-la sob todos os aspectos, a esgotar suas possibilidades. Entretanto, para além desses casos, é toda uma arte de reflexão diferente da nossa que está em jogo. Vasto, tema muito vasto!

Há outros perigos para a geografia humana: a tendência a tudo explicar pelo meio geográfico e biológico, ainda que assim se explique, fatalmente, apenas uma parte da realidade. Da mesma forma, o perigoso hábito de sempre falar do homem: o homem e a floresta, o homem e as ilhas, o homem e a montanha etc. É mister dizer os homens. Bem sei que nessas fórmulas habituais a palavra é tomada significando "humanidade", "povos", ${ }^{16}$ e eu também a empregarei nesse sentido. Porém, a dúvida subsiste. Escrevia Demangeon: "Renunciemos a considerar os homens como indivíduos". Certa ocasião, Brunhes disse: "Vejam vocês: o individualismo deve mesmo ser banido da geografia". Grandes palavras. O objeto, o centro da geografia humana, e, talvez, da geografia tout court da geografia "profunda" com a qual temos o direito de sonhar, não é o homem, mas a sociedade - verdadeiro ambiente do homem, onde ele se move tal como peixe dentro d'água. A geografia humana é o estudo da sociedade no espaço; diria, mesmo, pelo espaço, tal como em minha conferência anterior defini a história como o estudo da sociedade graças ao passado, esse "meio". O espaço também é um meio, um quadro menos sólido do que alguns pensavam, porém bem mais importante do que outros concebiam. Acrescento: geralmente, é da sociedade que é preciso partir, e não apenas de seu ambiente.

Em todo caso, é à sociedade que é necessário chegar. É bem estranho que a geografia, em particular a francesa, tão comumente esqueça o homem e, assim, pare no meio do caminho. De minha parte, isso não é um ataque gratuito. Vejam como poucos livros de geografia nos dizem o que o homem pode comer, a forma como se veste, o que canta, a língua que fala, o que pensa, o que crê. Há, no decorrer de várias páginas, um estranho homo geographicus. Se me lembro bem, ele é irmão do homo economicus, e, como este, tudo é feito por fora da vida. Esquecimento frequente do homem, dizemos nós, mas esquecimento habitual da sociedade entre nossos geógrafos franceses. Um dia, um filósofo estrangeiro verá neles, com prazer e júbilo, a prova de nosso individualismo. Queremos ser os únicos diante do Estado, os únicos diante da natureza - o que é uma forma, como outras, de resistir a esse grande movimento do pensamento contemporâneo. Ontem, descobríamos o homem, o homem centro do mundo. Hoje descobrimos a sociedade, este novo Deus... Descoberta ainda não consciente em todas as esferas do pensamento.

Da autoria de Pierre Monbeig, ${ }^{17}$ eis um excelente estudo, vivo, direto, sobre a zona do cacau de Ilhéus, no estado da Bahia. Nele, tudo se deduz com exatidão e precisão. Excelente trabalho. Todavia, não nos diz nada, ou diz com dificuldade, acerca da sociedade dessa zona pioneira, de onde ela veio, como ela se formou. Desde 1840, nessa floresta litorânea de Ilhéus, floresta ao longo da beira do mar, colonos suíços e alemães estabeleceram as primeiras clareiras, as primeiras plantações de cacau. Otto Quelle contou-nos sua medíocre e heroica história. Segunda ocupação: para dizer a verdade, um movimento intenso, por volta de 
1890. Situados no interior da Bahia, arruinados pela concorrência longínqua das minas do Transvaal, caçadores de ouro (raça de aventureiros, de feras) refluíram então para a costa e, determinados, lançaram-se sobre as terras penosamente desmatadas de Ilhéus. Desde sua chegada, o resto do pays, incendiando-se em disputas, ficará agitado, e a zona pioneira viverá, graças a eles e também a despeito deles, seus primeiros grandes momentos. Os aventureiros retomaram e completaram a obra inicial dos nórdicos, criaram o reino do cacau e do suor, da dificuldade dos homens - cacau e suor, como diz tão bem o belo romance populista de Jorge Amado. ${ }^{18}$ Agora, toda essa violenta história nos é revelada, e, por trás dela, o papel dos mercadores portugueses da Bahia, amantes de grossas somas de dinheiro, mercadores de escravos, de caixas de bacalhau, de carne de sol. Senhores das mansões, do mercado, do porto e dos veleiros da cidade baixa. Enfim, credores sem os quais nada teria sido possível no Sul... Estranha imperfeição, não é verdade?

Muito comumente, nossos geógrafos negligenciam, em seu campo de estudos, não diria o homem, mas o social. Sem dúvida porque investiga de muito perto os ambientes geográfico e biológico, o geógrafo se esgota nessas tarefas fáceis porém numerosas em torno de solo, relevo, clima, plantas e animais. Tarefas fáceis, quero dizer, porque tornadas fáceis graças a tantos trabalhos-modelo, esclarecedores, sendo suficiente adaptá-los. Em todo caso, muita geografia física - o que normalmente quer dizer muito nível de erosão, plataformas litorâneas, geologia. Tudo isso rejeita o homem e o social, colocando-os em segundo plano. Qual geógrafo (aprendiz ou experiente) não ouviu falar na boutonnière du pays de Bray?, ${ }^{19}$ ao passo que esse mesmo geógrafo nada saberia dizer sobre o campesinato ou as cidades dessa região de vivas águas. Que os especialistas façam essa experiência!

Imaginemos o homem, os homens, "o ambiente humano", como diz André Cholley. Não esqueçamos as realidades dos grupos e das comunidades, a solidariedade dos laços sociais, tudo o que liga o homem ao homem e faz da sociedade instalada no espaço um tecido vivo, com malhas mais ou menos compactas... São elas, as realidades sociais, que a geografia deve nos explicar ou, ao menos, ajudar a explicar. Para nós, a geografia é tanto um método quanto uma ciência...

De fato, não existe problema social que não esteja situado em seu quadro geográfico, quer dizer, exposto no espaço, confrontado a esse espaço. Não há realidade social que não ocupe um lugar no solo. Esse ou aquele lugar: eis já todo um problema! Situar os fatos a serem estudados: eis mesmo a primeira démarche de toda pesquisa social séria. A esse respeito, é preciso citar os estudos clássicos e tão conhecidos de geografia política de André Siegfried acerca do maciço armoricano (e sua curiosa fronteira política a leste), da França, da Inglaterra e dos EUA? É necessário mencionar os estudos recentes (e de forte interesse) de Gabriel Le Bras sobre o catolicismo francês, realizados a partir de documentos diocesanos? Ele transpôs no mapa regiões de fervor religioso e regiões de, em certos momentos, total indiferença religiosa. Eis aqui uma geografia do catolicismo francês ou, ao menos, seu esboço. Cabe a nós seguir seu rastro. Porém, agora que tais problemas já estão projetados no espaço, o autor se encarregará de observar os fatos tão relevantemente assinalados pela localização. Aqui os geômetras 
falariam de um vestígio de fatos sociais sobre o plano geográfico. Não saberia dizer até que ponto traços semelhantes são, em geral, ricos de indicações. Guardadas as devidas proporções, é algo como um registro, a fotografia de um movimento em uma pesquisa de física mecânica, com a geografia oferecendo-nos, no caso em questão, bem mais que um instantâneo.

Para a história, que auxílio o da geografia! Não retornarei ao já citado exemplo dos estudos de Émile-Félix Gautier. Vocês os conhecem, eles fazem sucesso em nossas bibliotecas do campo. ${ }^{20}$ Estabelecer os fatos históricos no espaço é a melhor forma de compreendê-los e de situar os verdadeiros problemas com maior precisão.

Vejamos Lorena e Barrois às vésperas da Revolução Francesa, pouco após sua união oficial à França em 1766 na época da morte de Stanislas Leczinski. De fato, a anexação real remontava à paz de Viena em 1738. Ademais, não esqueçamos que, pelo menos desde o século XVI, Lorena sempre esteve à mercê dos exércitos franceses, e, sobretudo, que toda ela era de língua e civilização francesas até a fronteira germânica além de Metz. Tal Lorena? Um pobre e magro pays arborizado, alagadiço, arenoso, de vindimas sempre incertas mesmo em seus pontos mais favorecidos e "agricultores" geralmente miseráveis. Aliás, pobres "camponeses" [manants] colhedores de uvas verdes (ah! Nossos grandes vinhedos de Bar-le-Duc ou do pays messin). ${ }^{21}$ No século XVIII Lorena conhecerá múltiplas mudanças, quase um despertar. Se atentarmos para suas aldeias percebemos que todas ou quase todas aumentaram a superfície de suas terras cultiváveis, ampliaram o perímetro de suas extensões. Vocês conhecem essas clássicas aldeias lorenas: no centro, as casas amontoadas umas sobre as outras, apertadas em fileira dupla ao longo da estrada transformada em celeiro; ao redor de tudo, as lavouras, quer dizer, um largo disco com suas três "estações" diferentemente nuançadas: trigos, aveias e "pousio" [versaines]. Enfim, ao redor do círculo, cortando as pequenas colinas calcárias e recobrindo os terrenos mais longínquos, a floresta e sua longa linha azul desenhando o horizonte. Aldeias, campos, bosques: três zonas, três gêneros de vida: a sopa, o trabalho cotidiano, as notáveis ocupações dos lenhadores. Aqui, na reentrância das casas, vive-se, ama-se e discute-se com os seus, durante todo o tempo, a dureza da vida - tanto pior se o vizinho escuta, pois é para ele mesmo que se grita. Mais ao longe, nos altiplanos, trabalha-se: corte do feno, nova ceifa, colheita dos trigos (com as marmitas de sopa quente ao meio-dia), fatigantes labutas de foice e de reunião dos feixes de trigo. Os desesperados, quando existem (e eles existem), encontram-se na floresta, esse mundo de pobres e de condenados hostil ao homem; zona de refúgio (ainda em 1870, refúgio diante do inimigo), zona sempre temida.

Permanecida intacta desde o século XIII, no século XVIII a linha de bosques foi invadida em vários pontos, e só a partir de então foram fundadas as grandes fazendas isoladas desses novos lugarejos - em geral, em solos não muito férteis. No século XIII, aldeias novas como Laneville, Neufville ou Neuveville haviam ocupado o terreno conquistado e continuaram a montar guarda diante de seus bosques - geralmente nas gargantas florestais ameaçadoras ou entre a floresta e o vale. Nessas circunstâncias, construídas por grandes proprietários, burgueses ou nobres, apenas as fazendas foram muito afastadas das aldeias. Elas adentraram em florestas inóspitas, situadas sobre solos normalmente cobertos por pântanos e samambaias. Todas essas fazendas subsistiram, vegetaram até o presente. Desde antes de 1914, elas só se mantinham graças à mão de obra de trabalhadores estrangeiros (luxemburguenses, alsacianos ou alemães) 
na província. Elas eram e permanecem objeto de invejas, suspeitas e fofocas malevolentes, vocês podem adivinhá-las.

Esse crescimento dos terroirs no século XVIII estava ligado a um aumento da população lorena e ao uso (tornado necessário) de novos métodos agrários. Literalmente, Lorena transbordava camponeses. Eram inúmeros os pobres e os itinerantes - estes últimos, trabalhadores em busca de emprego, tais como estanhadores, caldeireiros, cesteiros, sapateiros (os de Condé-en-Barrois) e carroçeiros (os de Rembercourt-aux-Pots eram famosos desde o século XVI). Uma cadeia contínua levava as árvores abatidas do Vosges a Bar-le-Duc (então porto do bosque), onde carvalhos e pinheiros da montanha eram lançados ao rio Ornain e chegavam até ao rio Sena. Aumento demográfico: foi preciso aumentar os terrenos para alimentar essa população mais numerosa, e, sempre para fazê-la subsistir, a indústria se desenvolveu: tecelagem no Vosges, fundições e ferrarias nos vales do Meuse e do Ornaim e cervejarias nos futuros departamentos de Meuse e de Meurthe.

Eis o que nos ajuda a compreender, em linhas gerais, o drama que a Revolução representou para Lorena. Pode-se adivinhá-lo: todo seu proletariado agrário encontrou uma saída nos exércitos da República e do Império. Para os camponeses do leste essa foi uma grande aventura. Imaginemos que Lorena tivesse seguido os "federalistas" quando da louca insurreição girondina em 1793, se assim o fosse, em consequência de sua posição sobre as linhas de retaguarda dos exércitos combatentes, da defesa nacional e da revolução ao mesmo tempo. Porém, Lorena não se mexeu. Sem dúvida, ela não foi a única província a então salvar o país e a República. No entanto, notem que ela contribuiu bem para isso e que sua participação na aventura militar verdadeiramente a amalgamou à França, essa nova pátria. Não houve nenhuma cidade, e quase nenhuma aldeia, que não tenha, generosamente, considerado seus soldados e, com certeza, seus oficiais, mas também seus generais - desde Ney, nascido em Sarrelouis, a Excelmans e Oudinot, crias de Bar-le-Duc, o outro lado da terra lorena. Contudo, arrancaremos as páginas do Dictionnaire des généraux de la revolution et de l'Empire, de Six? Diz-se que a Lorena é uma região fronteiriça, e que isso explicaria toda sua psicologia. Mais precisamente, digamos que, a partir de 1792, ela foi uma zona de região militar, de verdadeiros cantões suíços. Ela foi, ela permanece, um pays de soldados, e isso a explica. Acrescentemos que é possível ser uma zona fronteiriça sem ser um pays de soldados. É com a revolução que começa o grande gesto militar de nossa Lorena.

Eu não diria que essa história do leste possa ser deduzida do aumento das terras cultiváveis, desse pequeno sinal geográfico. Com certeza, não. Porém, escolhido à revelia, tal exemplo nos mostra muito bem um aspecto geográfico de um amplo movimento histórico. Aqui, o fato geográfico é uma das malhas da cadeia, nada de mais. Todavia, é algo a ser considerado, pois sempre existe uma malha geográfica, e, às vezes, mais de uma, na cadeia dos fatos sociais. Que historiadores e demais cientistas não esqueçam isso! Aqui, como em outras ocasiões, a geografia não nos ajuda a ver tudo, mas a ver melhor.

Bem sei que certos geógrafos não gostarão desta segunda posição. Cada ciência humana sonha ser autossuficiente. Entretanto, esse não é um sonho perigoso e ilusório? Nosso estudo, a sociedade, ultrapassa os meios de cada uma das ciências tomadas separadamente. Cabe a nós congregar nossos esforços e reunir nossos resultados. Creio mesmo que a geografia dita humana faria progressos decisivos se tivesse uma nítida consciência dos limites de seu 
método, caso se persuadisse da necessidade (onde ela existir) de ligar-se às demais ciências do homem - tal como ela associou-se, para desenvolver-se, às ciências da natureza, no que concerne às suas bases físicas e biológicas. A geografia humana também avançaria se partisse nem sempre da terra, repitamos, mas também da própria sociedade, uma sociedade a restituir, ela e seus problemas, no espaço. Que missão! Geógrafos: é das necessidades, das realidades dos problemas do social que gostaríamos de partir - mesmo que seja uma exposição sistemática. A natureza não prevalece frente ao homem. Partir dela é, normalmente, perder-se, andar às cegas, delimitar mal as verdadeiras questões.

Se Febvre ataca, sistematicamente, o determinismo geográfico, a presumida ligação do físico ao homem, o fato é que, se eu o compreendo bem, em nossa investigação das causas e dos efeitos ao partir da natureza para chegar à sociedade, nosso fio se rompe no meio do caminho, explicamos mal, não explicamos nada. Quando, ao contrário de Karl Haushofer, Gaston Roupnel afirma a primazia do tempo - realidade das realidades sociais e da vida dizendo "antes de tudo, somos os fluxos desse movimento [o movimento da duração], os instantes desse impossível percurso do qual somos apenas a argila da terra", ele também nos aconselha a inverter os termos do problema geográfico. Partir não da argila, mas do homem. Igualmente, quando Jean Brunhes escreve sua tese sobre a irrigação na Península Ibérica e na África do Norte (1902), ele escapa do quadro regional restrito ultrapassando o exemplo, o particular, e acentuando o trabalho humano... Naquele tempo, e ainda hoje, bela novidade. Em Les éléments biologiques de la géographie humaine: essai d'une écologie humaine (1942), Maximilien Sorre me parece ter, de um lado, concluído a geografia biológica (concluído temporariamente, bem entendido) e, de outro, insistido, com força, sobre a necessidade de ver o meio físico não mais por si mesmo, mas sim à medida do homem - e essa é uma revolução a perpetrar. Eis um progresso incontestável, um salutar renascimento do habitual problema geográfico: a substituição da medida do homem, de uma vez por todas, pela medida dos homens, dos grupos, das sociedades. Assim, desejaria articular essa geografia a uma sociologia amplamente assimilada entre os franceses, tal como a de um Marcel Mauss ou de um Maurice Halbwachs, mas também à sociologia do livro de Robert, ${ }^{22}$ tão discutido na Alemanha, tão curioso e rico por conta de suas intenções... sobre os Alpes ocidentais da Estíria. Nessa sociologia pesquisarei quadros, verdadeiros problemas humanos - sem esquecer que o outro caminho, tão criticado e tão perigoso, que vai do meio físico ao social, permanece útil.

Em suma, dois polos: o social e o espacial. Ir de um ao outro e, em seguida, fazer a rota no sentido inverso. A sociedade projeta-se no espaço, aderindo a ele: em seus casos concretos, a sociedade é composta por alguns homens e um pouco de terra. Compreender essa aderência como um molde e, por meio dele, explicar a sociedade: eis o que solicito aos velhos e novos influentes da geografia. Não sou o único a lhes fazer tal pedido. É sempre nos limites dos campos científicos que se colocam os grandes problemas. No que concerne à geografia, esses problemas se situam entre suas pesquisas, conceitos e métodos e os vastos canteiros das ciências do homem.

Mal e rapidamente esboçado, eis a questão geográfica tal como a vejo. Talvez, um dos maiores problemas "sociológicos" e, inevitavelmente, um grande problema de história. A saber, o das ligações entre o ambiente humano e o espaço, entendendo a palavra espaço no sentido tão rico de environnement dos geógrafos americanos. 
Agora, se acrescentarmos ao espaço e ao social a poderosa coordenada "tempo", ${ }^{23}$ teremos uma formulação rápida, porém nítida, da geo-história e do próprio tema desta conferência.

\section{O trinômio dos geógrafos alemães: Raum, Wirtschaft, Gesellschaft}

"Ao lado dos fatores geográficos há, pois, um fator tempo" (André Siegfried, Cours de géographie économique, 1941).

O geógrafo trabalha sobre o atual, sobre o mundo tal como ele é - essa é sua fraqueza e sua força. E se, como frequentemente o faz, invoca o passado, não o faz pelo próprio passado, mas como explicação do tempo presente. Tentar transpor esse trabalho ao passado; perguntar, por exemplo, qual foi a geografia humana social da França à época de Luís XIII ou dessa ou daquela parte da América pré-colombiana: eis o programa da geo-história. Aliás, tais questões não são menos ricas para o conhecimento do social que exemplos estritamente atuais, muito pelo contrário. E não falo de seu interesse direto para a história. Ver não apenas as glórias da política de Richelieu, mas mostrar como a condenável Guerra dos Trinta Anos arrasou toda nossa França do Leste como um vulgar compartimento da Alemanha, desprovendo Bourgogne e Lorena de homens e cortando-nos da Europa Central. Tarefa de geógrafos, mas também de historiadores.

Expliquemo-nos de outra forma: a vida de uma sociedade depende de fatores físicos e biológicos; ela está em contato, em simbiose com eles, que modelam, ajudam ou atrapalham sua vida e, portanto, sua história... Não toda a história, mas uma parte. É a essa parte que propomos a expressão "geo-história". ${ }^{24}$

Em livro recente, ocupei-me da história do Mediterrâneo no século XVI. ${ }^{25}$ Dito assim, entendi apreender não apenas a história dos governos e das frotas de guerra, das economias, das sociedades e das civilizações, de todos esses passados suntuosos, mas também a história repetitiva, porém pujante e rica, dessas permanentes coerções que são o relevo, os solos, os climas, os ambientes da vida. Tento reencontrar a importância constante, orgânica, da repartição das terras e dos mares, o papel histórico regular das estações. Pois, no século XVI, com suas coibições, seus efeitos e suas criações, as estações são fatores históricos - tal como hoje. Em uma "ressureição integral do passado", seria inteligente esquecê-las? E se, como eu penso, esses simples movimentos do tempo, tais como os cultivos de primavera e o retorno do inverno, ritmarem, para além da vida dos mundos camponeses - o que se explica por si mesmo -, o comércio e a própria "grande história", a dos príncipes e dos diplomatas? Disputar com o inverno no século XVI? Usualmente, não. Navegar no inverno? Normalmente, não. Ele é um período de vida lento, em geral de trabalhos domésticos. Nessa época, os únicos que negociam são os grandes Estados-Maiores da política. O inverno é sua estação, a dos projetos e das negociações, e isso nos explica muitas coisas.

Eis o que me impeliu, para enriquecer os habituais conceitos tão estreitos da geografia histórica, a ampliar a empreitada dos geopolíticos alemães ao estudo integral do passado - e não apenas ao passado dos Estados, como eles o fazem. Essa "política única" dos geopolíticos de Munique, seu desejo de passar o materialismo econômico por um determinismo geográfico 
(porém limitado ao plano político), parece-me uma posição muitíssimo estreita - por mais original que seja. Assim, introduzir a coordenada tempo no problema geográfico é considerar a geografia humana como historiador em todo o conjunto vivo de seus problemas, de suas ligações de causa e efeito. É vê-la variar os elementos - oportunidade de melhor compreender tais problemas, pois o tempo é uma medida, uma das maiores realidades do mundo e da vida. Experiência enorme a resumir, é verdade, e sobre a qual não podemos fornecer aqui senão alguns esboços ... ${ }^{26}$ de uma perspectiva de conjunto.

Para simplificar, reportemo-nos, inicialmente, às amplas e habituais divisões dos geógrafos alemães. Seus estudos dividem-se em três blocos constantes: Raum (espaço), Wirtschaft (economia), Gesellschaft (sociedade). Apenas o primeiro termo carece de explicação. Em linhas gerais, Raum é o environnement ${ }^{27}$ dos geógrafos americanos; de modo ainda mais preciso, é, simultaneamente, o meio geográfico, físico e biológico dos geógrafos franceses. Em suma, é o espaço com todas as suas características físicas, quero dizer, os espaços terrestre, líquido e aéreo, essas três dimensões do homem com todas as suas possibilidades, riquezas e coerções. Tão em voga nos estudos alemães, a vantagem da palavra espaço é perceptível: ela sintetiza todo um complexo de fatores e de agentes geográficos; permite designar, com um único vocábulo, todas as incontáveis forças que perfazem o determinismo geográfico e criam o hábito de ligá-las em um único conjunto. Em nossas discussões, temos forte tendência a dividir o todo, a fragmentá-lo, para examinar suas partes e minimizar sua influência, quando talvez seja o "todo" 28 o que importa observar. Em relação ao espaço, a economia (Wirtschaft) será o conjunto dos ganhos do homem, ou, antes, do grupo, sua forma mais ou menos ativa de conquistá-lo e possuí-lo - sem esquecer a conexão do econômico com o social e o natural. Último termo do trinômio: sociedade (Gesellschaft). A palavra me parece excelente, bem mais rica que a expressão "geografia social", ${ }^{29}$ testada várias vezes.

Aceitemos essa terminologia sem muito discuti-la: espaço, economia, sociedade. Nossa proposta é mostrar, em linhas gerais, como essas realidades variarão umas em relação às outras no decorrer do tempo; como a ação vai, com os anos e os séculos, de um a outro desses fatores para, depois, retornar e retornar, e assim sucessivamente... Preciso dizer a vocês que a economia modela o social e o espaço, que o espaço comanda a economia e o social e que, por sua vez, o social comanda as outras duas realidades. Estamos aqui em um mundo de ações, reações, interações. Já mencionaram que "o geógrafo deve estudar a ação que a sociedade exerce sobre o solo, sociedade essa que já sofreu a ação de tal solo".${ }^{30} \mathrm{O}$ homem é causa e efeito ao mesmo tempo - diz-se com frequência. Imaginemos uma pedra que bate na água incessantemente...

Dito isso, tomemos exemplos simples, observados globalmente, visando a uma elucidação sumária dos problemas.

Em uma sociedade numerosa, de imediato a economia e o espaço se modificam, pelo menos o espaço ocupado e trabalhado pelo homem. Falávamos sobre isso a propósito da Lorena em 1789; a fortiori, e o exemplo seria mais convincente, poderíamos dizê-lo acerca da superpovoada Europa dos séculos XII e XIII - na época, freneticamente em busca de novas terras a conquistar por sobre florestas, pântanos e mar. Porém, poderíamos perguntar: de onde veio esse incremento demográfico? Deixando de lado razões ainda misteriosas (Marc Bloch), não poderá ter vindo de causas econômicas? Assim se fecharia, deve se fechar na realidade, a cadeia das causas, das consequências e das concomitâncias, cujos fatos sociais não 
representam todos os elos. Experiência inversa: uma sociedade declina, um pays se despovoa, terras menos férteis são progressivamente abandonadas aqui e ali. É o caso da França rural em 1936. Segundo Gaston Roupnel, bom observador desses temas, tal recuo é visível nas margens dos campos inférteis, nas extremidades das florestas. Recuo perceptível demais para ser negado. Eis um sinal revelador sobre a sociedade nacional.

Outras variações. Dessa vez, as da economia. Suas consequências são imediatas e nítidas em todas as direções: de um lado, elas são marcadas por mudanças espaciais, e, de outro, por alterações sociais. Vejam a Inglaterra nos séculos XVIII e XIX convulsionada por sua revolução industrial, contraindo-se, reduzindo-se a seus pays noirs ${ }^{31}$ e deixando praticamente vazio o resto do seu espaço, abandonando-o ao crescimento das árvores, às pradarias, aos brejos e aos campos pantanosos povoados de raposas. Aliás, nessa mesma época, vejam todas as agitações sociais e, inclusive, as agitações da própria Inglaterra, inúteis de comentar aqui.

Por volta de 1890, na Argélia, no Alto Atlas, com a mula sendo substituída pelo boi, o arado permite o estabelecimento de uma zona de trigo e a multiplicação das fazendas europeias, assim como, consequentemente, a redução dos espaços reservados até então à vida pastoral dos nativos. Também aqui (como, aliás, em todos os lugares) uma revolução econômica teve consequências nos dois sentidos (espacial e social), tal como era possível prever facilmente.

Muitos autores alemães, de fato, pensam que a vida econômica se organiza por si mesma em espaços mais ou menos vastos, em economias-mundo (Weltwirtschaften), tal como fora o Mediterrâneo no mundo antigo. A economia-mundo atual seria a reunião, mais ou menos bem feita, mais ou menos amalgamada, dessas economias-mundo. Especificidade espacial da economia!

Todas essas turbulências traduzem-se no mapa. A sociedade utiliza o espaço, vive nele, organiza-o, emprega-o. Nessa simbiose, imaginemos avanços, mas também recuos; dilapidações, mas também reservas. Pausas necessárias, talvez, segundo ritmos que percebemos com dificuldade, com equilíbrios: no coração continental da Europa do Oeste, a forte estabilidade do campesinato (a esse respeito, ver o belo livro de Gaston Roupnel Histoire de la campagne française, que será amplamente comentado). Igualmente, o antigo equilíbrio nas bordas do mar Interior; depois, enormes rupturas no Ocidente nos séculos XIII, XVI e XVIII. Em seguida, outras harmonias, e assim sucessivamente. $\mathrm{O}$ espaço foi dominado, tragado, digerido em fatias. No decorrer dessa trajetória houve diversos equilíbrios econômicos entre o espaço e a sociedade. Assim, certas paisagens agrárias são paisagens de equilíbrio. Outras, nos países americanos, são paisagens instáveis, anárquicas, incoerentes, em revolução. Em um espaço ainda ilimitado, a sociedade americana, sem medida comum em relação às nossas civilizações europeias, é uma dilapidadora de solos e de riquezas. Tal como os cursos d'água, que possuem fases de juventude, maturidade e velhice em seus ciclos de erosão, certas paisagens são jovens, adultas e, depois, idosas. Então o homem não sabe mais animá-las e viver de sua ajuda...

Talvez só haja verdadeira prosperidade à medida que o espaço aproveitável não pare de aumentar diante dos homens. Um exemplo bastante preciso nos é fornecido por Creta Oriental. O geógrafo-arqueólogo A. Lehman dedicou-se a localizar suas raras camadas de solo fértil, pequenas ilhotas no interior de maciços calcários ou areníticos. Pode-se supor, porém, toda a ilha conforme essa estrutura: ela é uma sementeira de oásis, e é um desafio mostrar 
que das origens aos nossos dias a vida esteve prisioneira dessas minúsculas ilhas de terra móvel. Os depósitos pré-históricos, os restos clássicos, as ruínas das aldeias da época veneziana, as aldeias de hoje: tudo é encontrado no interior desses domínios estreitos, ora em direção ao mar, ora rumo às colinas ou sobre as primeiras encostas escarpadas, todavia jamais fora do horizonte das oliveiras e dos campos de cereais. Belo exemplo de determinismo de paisagens, de espaços agrícolas fixados ao solo. Contudo, seja no período minoico ou, mais tarde, no século XVI de nossa era, quando acrescenta a essas riquezas de base as riquezas do espaço marítimo, Creta não é próspera. Ela depende das viagens, da aventura, do vasto mundo d'além-mar, da ampliação dos espaços. Sem tais recursos não há prosperidade. Eis, porém, que a ilha povoa os mares com seus barcos ou com seus veleiros de carga e a riqueza aparece em suas cidades: origem, realidade de mil imperialismos de um passado longínquo que não é outra coisa senão a busca de um pouco de pão, azeite ou peixe seco.

Embora em um plano muito mais amplo e com desafios bem maiores, a história geral mostra-nos algo semelhante. À Antiguidade cercada pela bacia mediterrânea acrescenta-se, na Idade Média, o espaço de uma Europa bárbara, verdadeiro pays colonial às portas do Império Romano, verdadeiro pays "americano" com suas zonas pioneiras, seus cultivos precários, seus camponeses seminômades, suas cidades novas e seus "latifundia" (Henri Hauser adorava esta última comparação). Quando a Europa Central tinha vinte anos... No século XVI, nova ampliação, quando o domínio dos europeus estende-se ao mundo inteiro e a vastos espaços - em todo o caso, mal ocupados e mal explorados pelo homem até então. Assim, toda prosperidade corresponde a um dilatamento do espaço.

Entretanto, hoje, em 1942, a prosperidade está ameaçada - diz-nos o economista Ferdinand Fried após alguns outros. É que o globo está inteiramente conhecido; na acepção dos matemáticos, este mundo está finito e, como gosta de dizer Paul Valéry a acompanhá-los, deixou de ser elástico e deformável. Na direção dessas constatações pessimistas, declaramos ordinariamente: não há nada a fazer, exceto colonizar um planeta e, mais uma vez, aumentar o espaço da humanidade. De fato, a situação é tanto mais grave quanto uma exploração impensada é feita em nome de um único interesse, um interesse desumano: um imperdoável capitalismo, que utilizou o espaço alimentar do mundo e comprometeu seu futuro. A grande história que devemos enxergar é, talvez, a dos devastamentos florestais. Uma história muito antiga? Sim, sem dúvida. No entanto, eis que nos EUA a exploração do Meio-Oeste, das Pradarias, domínio ainda ontem de Bas-de-Cuir e dos heróis de Fenimore Cooper e, atualmente, zona do trigo, do milho e do algodão em direção ao sul, está comprometida pelas devastadoras cheias do Mississipi - consequência da devastação das nascentes. Ao suprimir as florestas, tudo se passa como se os diques de reservatórios naturais tivessem sido rompidos. De resto, o desaparecimento da cobertura vegetal da planície teve como efeito liberar os elementos móveis ao vento. As cheias, de um lado, e as tempestades de areia, do outro, desenvolvem-se como grandes calamidades. Toda a sorte do Meio-Leste fica comprometida. Para Ferdinand Fried, o resultado inelutável é a transformação da bacia do Mississipi em um vasto espaço, arruinado sob o peso dos homens, tanto pelas inundações quanto pelo assoreamento. Daí a necessidade de finalmente confiar à Tennessee Valley Authority a tarefa de regularizar todo o conjunto do sistema hidrológico para uma exploração eficaz. ${ }^{32}$ 
Da mesma forma, em outros lugares o homem também tem desencadeado contra si forças contrárias. Assim, ao desmatar, ele abre, no deserto nigeriano, o caminho do golfo da Guiné, rumo ao qual o deserto avança na proporção de um quilômetro por ano. Mesmo drama da seca na África do Sul, dessa vez em Kalahari. Drama semelhante na Austrália, onde o homem perde terreno para dois novos chegados: a figueira-da-barbaria (a despeito de seu nome, uma planta de origem mexicana) e o coelho, flagelo que não sabe mais dominar. Aqui, as forças biológicas se erguem contra o homem.

Tais exemplos são suficientes. Tantos outros poderiam ser fornecidos. Aliás, os exemplos precedentes são de responsabilidade de F. Fried. Tais e quais, verdadeiros ou não, creio que eles possuem a vantagem de colocar, de modo vivo, os problemas que nos preocupam. Porém, Fried tem razão? Eis uma outra questão. Esses exemplos devem ser admitidos com a reserva de serem verificados. Não aceito sem questionar que o mundo, como espaço vivente, tenha "terminado": tantas terras ainda inutilizadas estão para ser aproveitadas. Penso nas observações de Saint-Exupéry sobre o medonho vazio da Terra vista do céu, bem como sobre a restrita localização do homem ao longo de faixas, linhas de fontes e atividades férteis. Tantas terras ainda serão mais bem exploradas, tantas colonizações interiores a tentar, tantas descobertas ainda a fazer e, algumas, a desenvolver no decisivo domínio da biologia agrícola. Alguns geógrafos pensam que a Terra ainda pode suportar de cinco a sete bilhões de habitantes a mais que hoje: eis o que nos tranquiliza! Também desconfio de um economista que, pseudomédico como Fried, tem sua solução, suas soluções prontas. Ouçamo-lo: que o mundo renuncie ao capitalismo desumano. Que ele se resolva em espaços econômicos particulares: espaços europeu, russo, britânico, grande-asiático e americano. Em síntese, que o planeta se fragmente em planetas particulares; que o mundo se situe à medida do homem, e não, ao contrário, o homem à escala do mundo - o que é contra o bom senso. Vê-se de onde vem essa medicação, e eu não acredito em sua eficácia. Sua origem coloca-nos em alerta contra suas premissas e sua conclusão.

\section{O espaço varia por si mesmo?}

Além do mais, verdadeiramente é apenas o homem que, conforme sua cobiça, seus métodos e organização, modifica o espaço dado pela natureza? Seguramente não se olharmos o passado dos homens em toda sua amplidão, quer dizer, se acrescentarmos aos séculos de história os milênios da pré-história — de vinte a quinhentos milênios; de preferência, mais quinhentos que vinte. O tempo dos homens é suficientemente longo para ter sido marcado por vastas revoluções geográficas, das quais discernimos pelo menos as grandes mutações climáticas. O homem de Mauer foi descoberto às margens do Weser. Não é preciso dizer a vocês sobre o clima ou as atuais feições dessas margens fluviais. Porém, em um museu perto daqui, temos testemunhos irrefutáveis de um clima muito diferente. Imaginemos o Weser ${ }^{33}$ de então segundo o modelo do atual rio Níger. É necessário insistir? Conhecemos os dramas climáticos da pré-história: pressões de intensa friagem, com amplas progressões de geleiras e movimentos de fauna e de povos nórdicos rumo ao sul, bem como, pode-se imaginar, as contraofensivas meridionais empurrando suas plantas, seus animais e homens. Em seguida, períodos secos e quentes. A Europa atual foi o jogo de uma luta lenta, porém intensa e sem 
tréguas, entre o norte e o sul: um drama da latitude. O mundo das plantas, dos animais e, talvez, também o dos homens, sempre traz consigo essa marca. Na verdade, nós saímos de um longo passado no qual foi preciso lutar com a natureza e, além disso, contra suas mudanças.

Em nossos dias, a grande era dos neolíticos - veja-se, entre os franceses, Camille Jullian e Gaston Roupnel -, para citar apenas ela, não nos parece mais tão distante da vida atual quanto o fora em nossas especulações. No leste da França é possível encontrar nos caminhos côncavos dos camponeses neolíticos, com seus típicos bosques de espinhos, as fossas com as quais cercavam seus bosques e tantos outros vestígios (ferramentas, ossadas, gravuras). Faz muito tempo também que Robert Gottmann assinalou a existência de aldeias neolíticas instaladas nas clareiras naturais da floresta europeia do centro e do oeste, essas aldeias da velha terra (Altland) em oposição às da nova terra (Neuland) estabelecidas graças aos arroteamentos medievais. Se não inteiramente, um país como o nosso, pelo menos em seus vastos espaços do leste, é, por suas bases camponesas, neolítico. Marc Bloch nos lembrava que a palavra trigo e, sem dúvida, a planta - é um presente desses milênios obscuros. Tudo isso depõe para que a pré-história deixe de aparecer como ridícula ocupação de eruditos mais ou menos sensatos. Essa longa gestação da pré-história toca nas raízes, nas fibras mais profundas de nosso ser, e, com seu instrumental e suas civilizações despertadas, a era neolítica é o seu esplendor. Indo cada vez mais longe na análise do que reside em nosso interior, acabaremos por encontrar o que a pré-história sedimentou em camadas duplas, triplas, quádruplas, todas as angústias malresolvidas, as raivas e as necessidades selvagens do homem primitivo!

Cortada por grandes dramas, que admirável geo-história a desses milênios: de um lado, geleiras que avançam, batem em retirada, retornam e distanciam-se novamente; de outro, um Saara disseminado sucessivamente por lagos (lagos Tchad, diz Théodore Monod), deserto, novamente recoberto por lagos e, em seguida, deserto. Por duas vezes uma civilização provavelmente negra avançou, instalou, incrustou-se no espaço saariano. E em duas ocasiões ela foi arrasada pelo cataclismo, deixando atrás de si, em sua retirada colossal, civilizações residuais e um enorme material cultural, cuja coleta apenas começou: ferramentas, anzóis, machados, seda, raspadeiras, mós para triturar os grãos...

De fato, tais dramas geográficos, para ocorrer, demandaram uma inacreditável espessura de tempo.

O tempo histórico, ao contrário, é tão breve, tão breve - de quatro a cinco milênios em regiões privilegiadas, porém raras, como o Egito, e de um a dois milênios nas demais - que tais dramas não tiveram a possibilidade de se instalar. No que diz respeito a seus traços físicos, não foi o espaço reconhecido pelos domínios da história como um invariante, ${ }^{34} \mathrm{um}$ mobiliário? Porém, não é muito apressado dizê-lo?

Nossas medidas mais exatas apontam alterações mínimas, mas suficientemente constantes. Evidentemente, não saberíamos afiançar todas as observações feitas nos últimos vinte anos acerca desse grande problema. Porém, elas não deixam de ser bastante inquietantes. Bem sei que todos os historiadores de história antiga nos ensinam que o clima do Mediterrâneo era o mesmo que o de hoje no sul tunisiano, nas ilhas do Egeu (A. Jardé), no vale do Nilo (Fritz Jaeger, que, aliás, estendeu suas importantes constatações a toda a África) e em Palmira (ÉmileFélix Gautier). Contudo, essas e outras afirmações convergentes não resolvem o problema. Temos a prova das variações dos elementos naturais diante de nossos olhos, tais como 
mudanças longitudinais e latitudinais, iluminadas pelas teorias de Alfred Wegener. Assim, Nova Iorque afasta-se da Europa à baixíssima velocidade de um centímetro por ano, mas ainda assim se afasta. Do mesmo modo, a Córsega distancia-se do litoral francês em direção ao sul a uma velocidade anual de alguns milímetros. ${ }^{35}$ Estudo recente sobre os Alpes orientais também aponta um movimento geral da massa montanhosa rumo à Baviera na ordem de dois centímetros por ano, provocando desmoronamentos e deslizamentos de terra em pontos nevrálgicos, mencionados pela história em intervalos mais ou menos regulares quando dizem respeito à vida de certas aldeias. E, tal como no Mediterrâneo de ontem e no de hoje (Philippson), acontecem também variações litorâneas, e não apenas variações locais, ocorridas em virtude de perturbações igualmente locais (sismos ou erupções vulcânicas). Autoras como Dina Albani ${ }^{36}$ pensam em fases sucessivas de erosão e de colmatagem generalizadas, uma espécie de modulação da erosão marinha que, se estiver correta, colocará singulares problemas de física. Para o Mediterrâneo, a partir de 1900 teríamos entrado em uma etapa de erosão, com a costa recuando na África do Norte, no delta do Nilo e em algumas praias. O interessante desse movimento, se ele existir, seria sublinhar modulações em relação a um estado médio que, por si, permaneceria sensivelmente fixo. Por fim, alterações climáticas, sobre as quais queremos insistir. Aliás, elas são, de longe, as mais importantes, visto que parecem ter uma ação bastante direta (não digo rápida) sobre os homens.

Pela experiência e pela série de observações quantitativas, sabemos que os elementos do clima mudam. Restaria fixar o sentido dessas alterações e sua sazonalidade, caso existam. A esse respeito, não se falou em ciclos de doze anos, ligados, ainda que hipoteticamente, às manchas solares? Modificações do clima, pequenas transformações: conhecemo-las também mediante os maravilhosos estudos dos intelectuais americanos sobre a cronologia dos pueblos, essas aldeias indígenas do sul e do oeste dos EUA. Sabe-se que as árvores, seguindo a pluviosidade variável anual, crescem em camadas concêntricas de madeira, de espessura também variável. Assim, elas são higrômetros registradores. Graças a esses rudimentares testemunhos, tem sido possível distinguir os anos, reconstituir cadeias; enfim, datar os pueblos (alguns foram, quando muito, contemporâneos de Carlos Magno) de acordo com as árvores utilizadas em suas construções. Tudo isso representa um belo sucesso da engenhosidade científica. Porém, trata-se de uma simples curiosidade? Essa seria uma forma de completar as parcas observações de nossos documentos escritos sobre o "tempo", no sentido climático, dos anos que já se foram; talvez um meio de, por exemplo, resolver os problemas tão particulares da história climática dos Alpes. Como outras montanhas, os Alpes são, de fato, amplificadores das mudanças do clima. Imaginemos os avanços e os recuos das geleiras, acontecimentos que a história conservou a lembrança e, frequentemente, o impacto. Atualmente, o recuo é geral: nos Alpes orientais, o gelo descobriu grutas pré-históricas de excepcional interesse e minas de ouro que foram exploradas na Idade Média. Outra região sensível às mudanças climáticas, a borda da banquisa ártica oferece-nos observações análogas. Segundo constatações russas, no meridiano de Arkhangelsk ela tem recuado de 85 a 90 quilômetros desde 1880.

A respeito de tais temas, contestaremos as observações discutíveis, a insuficiência das pesquisas? Em todo caso, é fato que toda política de povoamento e de aparelhamento do norte soviético foi fundada, não sem reflexão, à luz da hipótese do reaquecimento do Ártico. 
A aventura prosseguirá, certamente. Aliás, ela é muito importante por nos trazer mais de um ensinamento e por revelá-lo.

No vasto domínio das mutações climáticas, entretanto, é prudente caminhar passo a passo, não se arriscar e aguardar, esperar novos balanços dos manuais científicos - única fonte, porém, de espíritos à deriva. Não foi o que pensou o geógrafo italiano V. Monterin em um bom estudo sobre os Alpes. ${ }^{37}$ Segundo ele, o clima variaria em amplos períodos de trezentos anos, sucessivamente frios e chuvosos, depois quentes e secos. Em 1300, começaria um período seco destinado a durar até 1600; em 1600, uma fase chuvosa o substituiria, indo até 1900. Em seguida, iniciaríamos um período seco por quase cinquenta anos. Não sei se essa lei é exata. Ela vale como hipótese. Restaria verificá-la de muito perto. De qualquer maneira, sabemos que em 1300 colonos alemães alcançaram as altas encostas do Monte Rosa, aproveitandose do reaquecimento e do recuo do limite florestal. Não é curioso constatar, dessa vez sob nossos olhos, com a fase seca que teria iniciado em 1900, uma colonização italiana das regiões superiores dos Alpes, dos Apeninos e, particularmente, dos Alpes apuanos? Inversamente, por volta de 1600, somos surpreendidos pela multiplicação de rigorosos invernos na península e por inundações devastadoras nos pays mais baixos, produtores de grãos. Na Itália, os séculos XVII e XVIII registram crescente aumento da malária. Verdadeiramente, isso não significa o avanço natural de uma doença geográfica que se ampliaria com o simples aumento das águas paradas? Perto de 1600 ocorre - historicamente, não é a primeira vez - uma espécie de progressão das águas malsãs no vale de Chianti, na Toscana. Curiosidade despertada, Gaston Roupnel se pergunta se as transformações climáticas não estão na origem das mudanças na Europa Ocidental dos séculos XIV e XV.

Verdade que tudo isso são simples e frágeis hipóteses. Estamos muito mal informados para concluir e também para situar corretamente os problemas. Entretanto, cada vez que nos lembrarmos de acusar o homem das transformações no espaço, desconfiemos! Não é questão de absolvê-lo. Mais precisamente, a questão é implicar tanto a natureza quanto o homem. Assim, conforme Goetz, as fontes superficiais se exauriram na Sicília do século IX. Diremos que a falta deveu-se aos desmatamentos e, portanto, ao homem? Ou que ela deve ser tributária de possíveis câmbios climáticos? Importantes questionamentos. Com suas políticas de irrigação e de dry-farming, ${ }^{38}$ será o muçulmano africano a trazer a solução para a escassez siciliana de água. Pode-se pensar, supor, que foi o dessecamento do clima que o fez avançar além do estreito da Sicília em 827. Igualmente, quando Ferdinand Fried acusa o homem e o capitalismo de vastos malfeitos aos quais ele aponta as consequências - ontem para o Meio-Oeste, hoje para o vale do Mississipi e as regiões fronteiriças do Kalahari e do Saara -, bem temos a impressão rápida e fugaz de que talvez a natureza também deva ser questionada.

Essa grande coisa, a natureza, talvez não seja assim tão inalterável quanto imaginamos à luz de nossas tão curtas experiências. Ao olhar da ciência, será verdade que existe uma única estabilidade no mundo que nos cerca? As coordenadas deste mundo modificam-se sob nossos pés ao ritmo de uma lentidão dificilmente imaginável. Pensemos nas rosas de Fontenelle, rosas que ele dotava de inteligência e para quem o jardineiro era imortal, realidade invariável. 


\section{Os dois sentidos da geo-história}

A discussão não está encerrada, e, sobretudo, nossa pesquisa não está finalizada. Seguramente, não queremos ver apenas o que Jean Brunhes denomina, com uma fórmula expressiva, "as responsabilidades do meio". Isso seria ver apenas uma face, um polo do problema: a natureza. Entretanto, e o homem? Quero dizer: e a sociedade? À sua maneira, Jean Brunhes assinala-o de maneira amável: "O vinicultor deve ser visto como mais importante que a vinha; o pastor, que o rebanho...". Em seguida, ele se repara, pois nesses domínios é preciso sempre fazê-lo: "Porém, sem a vinha não haveria vinicultor; sem o rebanho não haveria pastor...". Verdadeiramente, a geo-história é a história que o meio impôs aos homens, com sua constância (caso mais frequente) ou com suas ligeiras variações quando estas chegam a provocar consequências humanas. Quantas modificações, entretanto, permanecem despercebidas, negligenciáveis mesmo, por conta do frágil e curto alcance dos homens. Sim, decerto, mas a geo-história também é a história do homem em luta com seu espaço, batalhando contra ele ao longo de sua dura vida de dificuldades e esforços, conseguindo vencê-lo e, de preferência, suportá-lo, ao custo de um trabalho que é preciso sempre renovar. A geo-história é o estudo de uma dupla ligação: da natureza ao homem e do homem à natureza, o estudo de uma ação e de uma reação misturadas, confundidas, recomeçados sem fim na realidade de cada dia. É a própria qualidade, o poder desse empenho, que nos obriga a inverter a abordagem habitual do geógrafo.

Iniciada em meados do século XIX, vivemos numa época (ainda não finalizada) sob o signo da ciência e da técnica. É a era do engenheiro e da máquina, marcada pela progressiva emancipação do homem em relação à natureza - ainda não rematada, mas em vias de sê-lo. Não cantemos muito alto sua vitória, seu reino sobre a Terra. Hoje, contudo, bem mais que ontem, a determinação do homem, esse grande fator geográfico, não é real? Aliás, desde sempre, ela foi um fator considerável, uma vontade obstinada - e não apenas a que se refere ao camponês.

No século XV, tal como nos tempos antigos da lei Rhodienne, ${ }^{39}$ ou à época da viagem do apóstolo Paulo de Cesareia a Roma, o Mediterrâneo fechava anualmente de outubro a abril para as navegações. Nesse momento, as depressões de origem atlântica nele mantinham uma valsa desordenada de forma contínua, geralmente com ondas intensas. Imaginem o mar todo branco de espuma movimentado pelo Mistral, ${ }^{40}$ vasta superfície agitada de neve. Algumas vezes, mesmo hoje, são gastos um, dois dias seguidos para reunir todos os barcos que o sulcam em portos malprotegidos contra o vento, à época portos bem barulhentos por conta das sirenes dos rebocadores atados aos barcos em perigo. Portanto, no passado, antes do século XV, no tempo da vela, do remo e dos cascos de madeira, cargueiros e navios de guerra eram obrigados a passar o inverno em um porto apto para a atracagem, apto ad hiemandum. ${ }^{41}$ Barreira do mau tempo e das ondas, brumosas ondas: eis uma defesa de elementos que durante séculos tiveram seu papel, barreira tão insistente e tão constante que o historiador deve considerá-las. É uma das principais feições do mar Interior. Logo, fato geo-histórico de primeira categoria, ou seja, que vai da natureza ao homem. Porém, por volta de 1450, um novo tipo de navio procedente do Norte, o Kogge, foi introduzido no Mediterrâneo. Era um grande navio redondo e sólido, a "nave" dos documentos italianos. Fortemente fixadas, suas tábuas recobriam-se tal 
como as ardósias de um telhado. Não sem dificuldades, acidentes ou "acasos do mar", é essa robusta navegação que irá "vencer" o inverno mediterrâneo, ampliando, na própria época do Renascimento, o tráfego de rotas marítimas do mar Interior - explicado, a seu modo, por tal navio. Vitória do homem sobre a natureza? Sim, sobre o espaço, sobre o mar agitado: fato geo-histórico de segunda categoria. Aliás, nota-se, aqui, como as duas categorias se encontram e se misturam no real.

Evidentemente, não seguiremos em detalhes, com exemplos ou tentativas de classificação, essa segunda categoria de fatos. Tão diverso e complexo, esse combate contra a natureza sempre carrega a marca do homem, de sua determinação, de seus meios, variando conforme as épocas. No início, durante milênios, o homem lutou com armas medíocres por causa da proximidade de suas tribos (de caçadores), e foi com dificuldade que, do Neolítico ao Renascimento, e mesmo mais tarde, seus instrumentos se modificaram. De fato, para empregar a linguagem tão direta de André Siegfried, ${ }^{42}$ apenas passamos "da ferramenta para a máquina", ou, para retomar, literalmente, uma de suas frases, "César e Napoleão deslocaram-se da mesma forma. Este não avançou muito mais rápido que aquele". Retomando a mesma e importante constatação, Georges Duhamel disse que "o mundo mudou muito mais de Pascal aos nossos dias que das pirâmides a Pascal". Assim sendo, nos estudos de geo-história, o grande problema é tomar com cuidado a medida das capacidades humanas, fixar-lhes uma escala. Sem isso não há como compreender a ação do homem sobre o meio físico e biológico e, igualmente, a ação do meio sobre o homem, já que tudo está interligado!

Imagino a França das guerras religiosas. Vejamos tudo o que ganharíamos para entendêla fixando o que seria seu espaço material sob o prisma das distâncias. Para cartas e para viajantes, qual era o tempo necessário para suplantar a distância de Rennes a Rouen, de Paris a Bordeaux? Em relação ao tempo atual, a média era de oito a dez vezes mais para o mesmo trajeto. Uma enorme ampliação, portanto - não das riquezas desse espaço, muito pelo contrário, mas do obstáculo, do peso-pesado, da paralisia da distância. Aqui, buscar uma proporção exata entre o passado e o presente seria uma ilusão. Mas, enfim, quando falamos da França de Carlos IX ou de Henrique III, imaginamos um país tão vasto (não digo tão povoado) quanto a China atual. Exemplo esclarecedor este, dadas suas guerras civis, suas guerras externas e toda a sequela de misérias e atrocidades trazidas por tais calamidades. Como a França cindida do século XVI, a China tem seus generais comandantes de exércitos (os príncipes), seus bandos de mercenários saqueadores, seus camponeses proletários, seus campos arruinados e selvagens, suas cidades amedrontadas e vigilantes, tão desconfiadas quanto as cidades cercadas de muralhas e de fossos repletos d'água da Picardia de Condé, da Bretanha de Mercoeur ou da Borgonha de Mayenne. Relatos de narradores sobre essa guerra da China possuem traços comuns com nossas crônicas da França do século XVI.

Imensidão desta França e, de modo geral, da França do Antigo Regime. Em 1619, o duque de Épernon deixa Metz, onde é governador, com uma escolta bastante frágil. Pouco a pouco, ele chega a Blois, onde a rainha-mãe Maria de Médicis o aguardava. Não é surpreendente que ele passe despercebido - sim, pois assim ele o faz - neste enorme pays? Que deslize entre a vigilância? É como seguir uma agulha em um palheiro ou, atualmente, uma tropa chinesa deslocando-se em algum lugar da bacia de Wei-Ho. 
Diversidade da França monárquica, multiplicidade de suas liberdades locais, de seus privilégios de províncias ou de cidades. Tudo isso não se explica pela lentidão das chaises de poste ${ }^{43}$ das diligências e de mais outras coisas? Historiadores historizantes ${ }^{44}$ se perguntam se o objetivo de Henrique IV foi fazer isso ou aquilo. Tais historiadores não estão a par das demoras da estrada, dos atrasos das cartas e das respostas, das dificuldades de governar além do alcance da voz. Eles não levam em consideração exaustivas cavalgadas ou a rapidez do Béarnais, este nômade para quem a distância jamais fez graça, seja correndo de seus inimigos ou precipitando-se rumo a encontrá-los!

Essa luta contra a distância foi um dos grandes dramas do passado humano, um dos mais importantes - senão o mais importante. Hoje, o drama continua.

No entanto, verdade invariável: resultado das obras dos homens daquele tempo, grandes revoluções geográficas terão marcado etapas decisivas da história. Por volta do ano 2000 a.C., aparição do cavalo no Oriente Próximo, agitando a feliz calmaria. No século III de nossa era, surgimento do camelo no Saara Ocidental, ao lado dos cavalos tripolitanos. Emergência da "nave", cuja história contei há pouco. Em 1850, inicialmente no Atlântico Norte, aparece o barco a vapor de ferro, pavilhão de guerra inglês que repelirá do oceano seu rival, o barco de madeira movido a vela, campeão da época. Inútil falar do motor à explosão e de suas diversas e sucessivas aplicações (automóvel, caminhão, avião, cadeias de transmissão), o que significa evocar o período atual, cujo caráter revolucionário, ainda em ação, não nos escapa.

Notadamente, ver apenas a luta contra a distância é reduzir o combate do homem contra as forças da natureza, cometendo uma espécie de inversão implícita na palavra Raum. Essa não é minha intenção. Tomo o cuidado de não omitir as outras disputas do homem para estabelecer seus campos, florestas, gados, cidades, casas... Acerca da batalha por campos e hortas, irei abordá-la a seguir utilizando os belos trabalhos de Gaston Roupnel: o campo é uma criação humana, de suas ferramentas e de seus esforços, de suas comunidades. No que concerne às habitações, darei espaço considerável aos trabalhos do sociólogo-historiador Gilberto Freyre. ${ }^{45}$ Porém, entendam-me, não é possível seguir desde agora todos esses importantes problemas um a um. Se insisto aqui no duelo contra a distância é, simplesmente, porque quero evidenciar um dos setores mais relevantes e mais diretamente acessíveis da ação humana sobre as coisas: o espaço marítimo, que, em sua introdução geopolítica à história, Karl Haushofer ${ }^{46}$ afirma ter sido o mais decisivo dos espaços da história. É que ele é a grande rota, o grande meio de conduzir, de transportar homens e mercadorias. Jamais a via férrea e a via fluvial e, dificilmente, a aérea, terão o fluxo decisivo do espaço marítimo. Ele é o espaço da grande, da história muito ampla. Não há estradas a construir sobre esse mundo aquático ideal, aberto a todas as proas. Não há animais a atrelar. Até a chegada dos navios movidos a vapor e a óleo diesel, o homem e, principalmente, o vento eram suficientes. Que o essencial da vida dos homens tenha sido edificado sobre os mares: que profunda realidade! E que conquista, pois é o espaço terrestre, e não o aquático, o espaço dado, a coordenada de base. O espaço aquático foi conquistado com mais dificuldade que o mundo aéreo, que usufruímos atualmente. Os historiadores observaram tal ponto, mas nem sempre iluminaram bem essa verdade fundamental. Com efeito, não sabemos até que ponto as ciências históricas permanecem fixadas a solos firmes, a espaços bem sólidos, ricos em terra... Para muitos espíritos, nada de aldeias, de paróquias ou de história! 
Ora, o que não teríamos a dizer acerca da pujante história da navegação! A quantidade de relatos sobre as viagens marítimas do passado nos permitem, aqui, mensurar o passar do tempo. No século XVI, leiamos a viagem de tão vivos matizes de Jean de Léry, ${ }^{47}$ esse genebrino de Borgonha e colono do Forte Coligny na baía onde, mais tarde, crescerá a cidade do Rio de Janeiro. Ele nos conta suas duas travessias (França-Brasil-França), navegando o mais próximo possível da superfície da água, em contato com as realidades do oceano que ele praticamente toca com as mãos e que nós as percebemos sobretudo de longe, da terceira classe de nossos cargueiros, problema de nível e de velocidade... Os cardumes, as enormes "jangadas"48 de caviar, espuma avermelhada devorada pela fauna marinha. Havíamos observado, do alto de nossas confortáveis viagens, essa vida de superfície? Arriscamo-nos a morrer de fome durante a travessia ou alguns dias após a chegada, como frequentemente era regra?

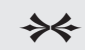

Assim, temos duas geo-histórias: uma, representada pelos homens; a outra, pela natureza. De fato, duas correntes de velocidades diferentes.

Do lado da natureza, a influência do meio é, em linhas gerais, imutável. Ela se coloca em termos naturais, que são sempre ou quase os mesmos - com a exceção, se existindo historicamente, confirmando a regra. Tal história é imóvel ${ }^{49}$ ou quase imóvel; quero dizer, indefinidamente repetida sob as mesmas condições e nas mesmas épocas. Exemplos: a descida dos rebanhos rumo às planícies no inverno e a subida para os altos pastos no verão. No hemisfério norte, colheitas e vindimas nos mesmos períodos do ano. O lodo: esse quinto elemento das terras polonesas e russas após o degelo da primavera, lodo vitorioso face à determinação dos exércitos alemães e russos, visto que ele já os imobilizara duas vezes de março a junho! Théodore Monod pôde encontrar a causa de certos aspectos da Bíblia à luz de suas lembranças do Saara, pois em seu campo de estudos a história não se mexeu. "Em todos os tempos", ele anota, "a pilhagem foi uma lucrativa indústria nos países desérticos, sendo natural encontrar no Antigo Testamento tantas dessas histórias que não são as de uma época, mas de um meio, e que estão fora do tempo; vertidas para a linguagem moderna, seriam a perfeita descrição de tal episódio saariano".

Eis agora o lado dos homens. Sua ação sobre as coisas varia conforme as épocas. Porém, ela é exercida lentamente, bem mais do que saberíamos concebê-la. Do lado dos homens existem revoluções geográficas - nós mesmos estamos em vias de viver uma -, mas elas demandam muito, muito tempo para se perpetrarem. Os primeiros navios aparecem no Mediterrâneo por volta de 1450, o último "galeão" mediterrâneo (velho tipo de barco de longa distância) atracará na Inglaterra em 1587. Da mesma forma, em relação ao que denominamos de conquista, não creiam que atualmente o automóvel tenha conquistado todo o planeta. Foi preciso a guerra de 1939-1943 para que finalmente ele tomasse posse do deserto; para que, no Saara, na Síria e alhures os triunfos massivos e repetidos da Guerra da Tripolitânia substituíssem as performances das vias de Bidon $V^{50}$ ou das caças às gazelas. Em 1932, a conclusão de uma experiência de ataque simulado ao oásis de Koufra foi reconhecer a impossibilidade do emprego de unidades motorizadas. Os méharistes ${ }^{51}$ haviam triunfado. 
No final das contas, no limite dos termos, duas histórias: uma, imóvel; a outra, muito, muito lenta, a despeito da insistente pressão do progresso...

\section{A unidade do mundo, aspecto geográfico da Revolução Industrial}

Uma das vitórias do homem sobre a distância e a natureza foi verdadeiramente o encolhimento do mundo e - consequência natural - de sua unidade. Se ontem o trecho CaracasBogotá era feito em 15 dias, hoje bastam três horas de avião. No Brasil, conta-se que as urnas de votação de determinadas vilas do sertão só chegavam ao Rio seis meses após as eleições. Hoje, alguns dias são suficientes. Sabe-se como o Atlântico é dominado pela linha aérea Nova Iorque-Lisboa via Açores (trajeto feito em 24 horas), bem como pela rota Natal-Dakar por meio dos "Courriers sud". Tudo isso não ocorre sem graves consequências - mais ou menos rápidas a surgir, mas que surgirão. Admirável tema de reflexão ao final desta conferência.

Unidade do mundo? Não creiam que isso seja uma simples imagem, um artifício, um clichê de discurso político, mas uma realidade muito, muito impressionante.

Durante milênios a humanidade teria vivido isolada, confinada em seus continentes tal como em espaços fechados, dispersa em tantos planetas - diz-se. No entanto, de planeta em planeta, de área civilizacional à área civilizacional vizinha, no decorrer dos séculos amarras foram rompidas, pontes estabelecidas, ligações necessárias multiplicadas, bens intercambiados. Inicialmente, tudo gota a gota: um pacote de seda, moedas com a efígie de Nero... Pouco a pouco, os povos vão descobrindo uns aos outros. Velha história. Neste momento, com o mundo vivendo tão rápido, hoje eles se articulam, permutam suas aparências e suas culturas. "Contatos eruptivos" - nota André Siegfried - são estabelecidos entre "civilizações manuais" e "civilizações mecânicas", verdadeiros choques elétricos. Tanto pior para os mais frágeis! Em uma Terra cada dia menor e mais sobrecarregada de gente - um bilhão e meio em 1914, dois bilhões em 1939! -, progressivamente falta espaço, e a proximidade torna-se regra. "O mundo é uma aldeia" - diz-nos Gaston Roupnel. Não vivemos mais sobre a Europa, mas sobre o mundo. A etapa Europa já foi queimada há algumas luas, e, ademais, malogrou três ou quatro vezes. Portanto, vivemos no mundo e, queiramos ou não, somos - para além dos intermediários que nos privam momentaneamente o horizonte - cidadãos do mundo. Isso não é um bem ou um mal. O que sabemos disso? Porém, trata-se de um fato. Conforme Eclesiastes, Id est quod est.

A internacionalização da cultura já é uma realidade; nada é mais móvel que os elementos culturais. Vejam os manuais de vocês: a ciência é internacional. A arte, também; ao menos, esforça-se. Aberta totalmente à luz, a arquitetura Le Corbusier - nua, geométrica, cúbica, tripla vitória do ferro, do cimento e do vidro - é implantada em todos os lugares, mesmo onde a intensidade do frio e da luz aparecem a priori como obstáculos consideráveis. De um lado ao outro do mundo é esboçada uma espécie de literatura (de romance ou de teatro) inteiramente dominada pela mesma aflição humana: uma extensa melopeia ${ }^{52} \mathrm{em}$ torno de uma reivindicação veemente, ampla, monótona, angustiada. Que seja mensurada a multidão dos que negam suas misérias, a quantidade dessas almas que querem ser elas mesmas e viver de suas vidas a despeito de tudo, como se nossa vida fosse nossa e estivesse - vejam só! - à nossa disposição... Não escolher, aconselhava $O$ imoralista, de André Gide; resguardar 
suas possibilidades, salvaguardá-las como um bem precioso retido ao alcance das mãos do naufrágio que nos ameaça a cada instante. Viver no limite da experiência humana, diz o grande Saint-Exupéry. Viver perigosamente, recomenda um terceiro... Porém, estamos livres dessa escolha, escolha que não seria única? Conforme suas leis provocadas pela técnica, mas da qual não somos os senhores, o mundo aglutina-se ao nosso redor e se solidifica como um cristal com uma assustadora indiferença à nossa sorte e à sorte de tudo o que amamos. No dia em que riquezas originais como os folclores locais tiverem sido exterminados pelas literaturas industriais, a uniformidade será ameaçadora para o pensamento e para a literatura - planta e sonho dos homens -, por todos os cantos similar e monocórdica.

A economia também é internacional: o capitalismo das empresas iniciou amplamente a conquista do globo, perpetrando a unidade do mundo à sua maneira. Mesmo o povoamento microbiano tende a equilibrar-se de um continente ao outro - dizem-nos os biólogos. É mister que cada um viva... Certamente, as doenças e as profilaxias também são internacionais.

Sob o peso dessa unidade, é também no plano mundial que as guerras são disputadas. Dizemos comumente que a grande guerra de 1914-1918 foi a Primeira Guerra Mundial. Eis a Segunda Guerra, não menos mundial que a precedente. Entretanto, 1914-1918 foi a Primeira Guerra Mundial? A engrenagem funcionava bem antes. As guerras revolucionárias e napoleônicas tiveram na Europa seu cenário mais espetacular. Porém, no mesmo momento, a Inglaterra ocupava as rotas do mundo e dominava a Índia - isso sendo tão importante quanto aquilo, em resumo. Os conflitos que nossos manuais dividem em capítulos sucessivos também são guerras mundiais: guerra de sucessão espanhola, guerra de sucessão austríaca, guerra dos sete anos. Também foram guerras mundiais as guerras tão diferentes que, desde o século XVI, foram promovidas contra o enorme Império Espanhol. Entre Pávia e Rocroi, por favor, não notemos somente a Europa. O mundo já existia. Desde que ele foi não apreendido e conquistado, mas apenas percebido, os homens o disputam. E, a partir do século XVI, quando a grande barreira do Atlântico - que, por muito tempo, dividira o ecúmeno em duas partes de maneira absurda - foi vencida, já existia um mundo cujas partes forçosamente se relacionavam. Em decorrência disso, houve uma história mundial [Weltgeschicte]. Bem mais vasto, o Pacífico não teve o papel de divisor absoluto entre a Ásia e a América: imaginemos as chegadas dos malaios à ilha de Páscoa e as migrações dos asiáticos rumo à América séculos antes de Colombo. Com a conquista definitiva do Atlântico pelos brancos, o mundo fechouse sobre si mesmo.

Como tantas outras forças que fazem a história e tecem o mundo, essa grandiosa unidade não é uma corrente contínua, mas uma corrente modulada, alternada. Sofre recuos e avanços, e é com essas idas e vindas que, finalmente, progride. Recuos? Avanços? Concebamos dois momentos próximos a nós. De início, 1914: um mundo aberto às mercadorias, às ideias, aos homens, a todas as trocas. Um verdadeiro mundo. Fazia-se uma volta nele, sobre ele, seu singular cartão de visita... 1939: reconheçamos que nos últimos vinte anos o mundo foi entrincheirado e fracionado de maneira absurda. Aqueles que não viveram esse insano recuo irão encontrá-lo no pequeno e admirável livro de Henri Hauser intitulado - por eufemismo, sem dúvida - La Paix économique (1935). Certamente, a viagem de Phileas Fogg no entreguerras teria suscitado não acidentes técnicos tal como no tempo de Júlio Verne em 1872, mas inextricáveis dificuldades de vistos e passaportes... 
Oscilação entre um mundo aberto e um mundo fortificado: o problema da guerra atual não é essa própria oscilação? Tratar-se-á de qual futuro? Do parcelamento da Terra em espaços autônomos, em planetas, tais como o espaço da Grande Alemanha e da Grande Ásia e os espaços ingleses, americanos, russos? Ou da manutenção, da salvaguarda da unidade do mundo?

Que esta última opção prevaleça: eis o que me parece provável. É de se imaginar que tal empreitada recusará, no futuro, fronteiras cerradas, economias planificadas, autarquias monstruosas! De 1919 a 1939, pudemos nos opor ao mundo por intermédio de uma ação desgastante. Honras sejam votadas ao egoísmo americano - a lei de 1924 sobre imigração, por exemplo. ${ }^{53}$ Também culpada, a Europa foi perdoada por suas loucuras e por sua fraqueza. Não se transforma impunemente em campo de batalha, não mais ontem que hoje. Para além dessa guerra, não penso que ainda seja possível conter e comprimir o mundo. Penso que ele vai abrir-se e contrair-se sobre si mesmo simultaneamente, todos os poros de uma vez. Talvez essa seja uma grande vantagem.

Os problemas do futuro, os grandes problemas, não os percebemos com nitidez? São os problemas dessas portas abertas, das vastas correntes de ar que agitarão nossas casas. Cuidado com velhos documentos, quero dizer, com velhos métodos, ideias antiquadas, civilizações e Estados de outrora.

Cooperação entre todos os homens de boa vontade: como não abandonar, por um instante, esse sonho natalino? Colaboração, cumplicidade, fraternidade, confiança em uma humanidade pacificada e melhor. Sonhos, não realidades imediatas, todos nós sabemos. Cumplicidade, sim, mas também lutas, lutas ferozes entre os vastos países e entre as raças do mundo inteiro. Entre as ideias, economias e loucuras do mundo inteiro. Entre os ódios, egoísmos e canibalismos de todo o mundo. Entre determinismos e fatalismos do mundo todo. Todos esses conflitos aparecem em suas longas e extraordinárias ligações no espaço. Quem nos garante que o destino de nosso mundo, a França, uma das ilhas do Ocidente, não esteja sendo elaborado hoje mesmo em determinada profundeza da China ou de outro mundo? Todos os países do universo se tocam e se misturam em um tumultuado corpo a corpo.

Por meio de minhas explicações e exemplos - sobretudo o grande exemplo da unidade do mundo, muito rapidamente abordado, lamento -, vejam vocês o que pode ser essa ampla camada de história e de vida, esse conjunto de fundamentos e de realidades perceptíveis, no plano das ligações geográficas, entre os homens e a terra que os suporta? Reconheçamos: a geografia projeta uma luz admirável sobre as complicações, sobre os milhões de fios da vida dos homens. Em todo estudo sobre o passado, em todo problema atual, reencontraremos sempre, na origem, essa zona - exigente, constante, luminosa o bastante para quem quiser observá-la - que designamos pela imperfeita expressão "geo-história". ${ }^{54} \mathrm{O}$ que historiadores (quase todos, pelo menos) e tantos especialistas do social e do atual têm feito é negligenciála. Adivinhem vocês as confusões e as inevitáveis consequências: visão incompleta do conjunto; problemas erroneamente colocados; realidades equivocadas; ênfase absurda no aspecto político. Insistamos: nossa sorte está sempre ligada à terra. Por mais lenta que seja essa história de base, ela é uma história, uma realidade da vida.

O perigo, pois ele ainda existe, seria o oposto daqueles que não reconhecem a geo-história: qual seja, perceber somente ela. Digamos com eloquência: a geo-história não é, e não pode ser, 
toda a história. Uma das fraquezas das admiráveis obras de Émile Félix-Gautier é justamente ter visto a história, com muita frequência, apenas com os olhos perspicazes e jovens de um geógrafo. Na verdade, precisamos de outros olhos para tudo ver ou, pelo menos, para tentar tudo ver e compreender.

\section{NOTAS}

* N.T.: Título original: "Géohistoire: la société, l'espace et le temps". Trata-se do terceiro capítulo de Les ambitions de l'histoire, Paris, Éditions de Fallois, p.68-114, 1997, coletânea organizada por Paule Braudel e Roselyne de Ayala com prefácio de Maurice Aymard. Esta tradução foi realizada no âmbito do Laboratório Política, Epistemologia e História da Geografia da Universidade Federal Rural do Rio de Janeiro (UFRRJ) por Guilherme Ribeiro (professor do Departamento de Geociências da UFRRJ e coordenador do laboratório). Agradecemos muitíssimo à editora de Fallois, que gentilmente autorizou a versão do presente artigo em língua portuguesa, assim como a intervenção do professor Paul Claval (Universidade de Paris-Sorbonne).

${ }^{1}$ N.T.: Braudel retornaria ao tema no artigo "Há uma geografia do indivíduo biológico?" (publicado originalmente em 1944), no qual dialoga com o livro Les bases biologiques de la Géographie humaine, essai d'une écologie de l’homme (1943), de Maximilien Sorre. O texto de Braudel é praticamente idêntico: "Os geógrafos o sabem: a geografia (como a história) é uma ciência muito inacabada, bem mais inacabada que as outras ciências do social. Talvez tão inacabada quanto a própria história, essa velha aventura intelectual" (Braudel, 2005, p.157). Ver Braudel, Fernand, Há uma geografia do indivíduo biológico? In: Braudel, Fernand, Escritos sobre a história, São Paulo, Perspectiva, 2005, p.143-160.

${ }^{2}$ Guide de l'étudiante en géographie, 1942.

${ }^{3}$ N.T.: Braudel faz menção às palestras antecedentes, que são "Trois définitions: l'événement, le hasard, le social" e "L'histoire à la recherche du monde". Junto com a presente tradução, as três compõem a primeira parte - L'histoire, mesure du monde - do já citado livro Les ambitions de l'histoire.

${ }^{4}$ N.T.: Personagem de Júlio Verne no livro $A$ volta ao mundo em oitenta dias.

${ }^{5}$ N.T.: Refere-se à tese de doutorado La Picardie et les régions voisines: Artois-Cambrésis-Beauvaisis, defendida na Sorbonne e publicada no mesmo ano pela Armand Colin. Mais informações sobre esse trabalho podem ser encontradas em Wolff, Denis, Une thèse qui fait date: "La Picardie" (1905). In: Wolff, Denis, Albert Demangeon (1872-1940) : de l'école communale à la chaire en Sorbonne, l'itinéraire d'un géographe moderne, Thèse (Doctorat en Géographie) - Université de Paris I, Paris, p.190-243. 2005.

${ }^{6}$ N.T.: Vidal de la Blache, Paul, Tableau de la géographie de la France, Paris, Hachette, 1903. À sua maneira, Braudel também fará um "quadro" da França apropriando-se dos legados de Vidal e de Michelet em seu último e incompleto livro: Braudel, Fernand, A identidade da França, Rio de Janeiro, Globo, 1986. Para ver dois estudos sobre o livro, ver Ribeiro, Guilherme, A geografia na formação do território francês: capítulos braudelianos de história do pensamento geográfico, Confins, v.10, n.10, p.1-20, 2010; e Ribeiro, Guilherme, História, historiografia e identidade nacional: Fernand Braudel e o caso francês, Projeto História, v.41, p.93$123,2010$.

${ }^{7}$ N.T.: Destaque nosso.

${ }^{8}$ N.T.: Trata-se de Les Pyrénées méditerranéennes: essai de géographie biologique, Paris, Armand Colin, 1913. Para maiores informações sobre Sorre em português, ver a coletânea de artigos organizada por Megale, Januário Francisco, Max Sorre, Coleção Grandes Cientistas Sociais, São Paulo, Ática, 1984.

${ }^{9}$ N.T.: Em sua temporada como professor do liceu e da universidade em Argel, Braudel inspira-se na perspectiva geográfica de Gautier (1864-1940), professor de geografia geral e de geografia do Saara durante 35 anos na Faculdade de Letras da Universidade de Argel. Além disso, reterá dele a dimensão geopolítica do Magreb e de seus papéis na vida do Mediterrâneo. Ver Paris, Erato, La genèse intellectuelle de l'oeuvre de Fernand Braudel: La Méditerranée et le monde méditerranéen à l'époque de Philippe II (1923-1947), Athènes, Institut de Recherches Néohelléniques/FNRS, 1999.

${ }^{10}$ N.T.: Dion, Roger, Le Val-de-Loire: étude de géographie régionale, Tours, Arrault, 1934. Dion (1896-1981) consagrou seus estudos sobre a geografia histórica da França, tornando-se um dos maiores representantes desse domínio no século XX.

${ }^{11}$ N.T.: Philippson, Alfred, Das Mittelmeergebiet, Leipzig, 1904. Em 1949, quando O Mediterrâneo é publicado, a primeira nota de rodapé menciona exatamente o livro de Philippson. Fiel ao seu temperamento, Braudel 
já o toma como um "texto envelhecido" (p.6). Isso não impede que o geógrafo alemão seja um dos mais citados em $O$ Mediterrâneo.

${ }^{12}$ N.T.: Versão em português: Vidal de la Blache, Paul, Princípios de geografia humana, Lisboa, Cosmos, 1954. Organizada por seu genro Emmanuel de Martonne, a edição portuguesa merecia maiores cuidados. O prefácio restringe o pensamento do geógrafo francês às relações homem-meio, e não situa o livro no âmbito de sua trajetória intelectual. Além disso, não alerta o leitor para o fato de que a "Introdução" é, na verdade, o artigo "Sur le sens et l'objet de la géographie humaine" (1912), escrito dez anos antes do surgimento dos Principes.

${ }^{13}$ N.T.: Versão em português: Demangeon, Albert, Problemas de geografia humana, Barcelona, Ômega, 1956.

${ }^{14}$ N.T.: Versão em português: Brunhes, Jean, Geografia humana, Rio de Janeiro, Fundo de Cultura, 1962.

${ }^{15}$ N.T.: Versão em português: Febvre, Lucien, A Terra e a evolução humana: introdução geográfica à história, Lisboa, Cosmos, 1991.

${ }^{16}$ N.T.: Destaques nossos.

17 "Colonisation, peuplement et plantation du cacao dans le sud de Bahia", Annales de géographie, 1937.

${ }^{18}$ N.T.: Embora Braudel refira-se a um único romance, Cacau (1933) e Suor (1934) são, de fato, obras distintas. A confusão é mais que perdoável, pois, na condição de prisioneiro de guerra, ele tinha acesso apenas às bibliotecas dos campos militares e aos livros enviados pelo orientador e amigo Lucien Febvre (1878-1956).

${ }^{19}$ N.T.: Depressão devido a erosão no cume de um anticlinal.

${ }^{20}$ N.T.: "Campo", aqui, refere-se ao terreno militar no qual Braudel estava confinado e onde escreveu este artigo proferido como palestra.

${ }^{21}$ N.T.: Pays localizado na Moselle, nordeste da França.

${ }^{22}$ Nota de Roselyne de Ayala e Paule Braudel, organizadoras do livro Les ambitions de l'histoire: "Nome do autor cujo sobrenome não foi citado no manuscrito".

${ }^{23}$ N.T.: Destaque nosso.

${ }^{24}$ N.T.: Destaque nosso.

${ }^{25}$ N.T.: Refere-se notadamente a La Méditerranée et le monde méditerranéen à l'époque de Philippe II, tese de doutorado defendida na Sorbonne em 1947 e publicada pela editora Armand Colin dois anos depois. A tradução em português publicada pela editora Martins Fontes refere-se à edição de 1966, versão modificada pelo próprio Braudel em relação ao texto de 1949.

${ }^{26}$ N.T.: Lacuna presente na versão original.

${ }^{27}$ N.T.: Destaque nosso.

${ }^{28}$ N.T.: Destaque nosso.

${ }^{29}$ N.T.: Destaque nosso.

${ }^{30}$ Nota de Roselyne de Ayala e Paule Braudel: “Uma anotação bibliográfica pouco legível indica R. Daude ou Dande".

${ }^{31}$ N.T.: Correspondente à região inglesa denominada Black Country, fortemente industrializada a partir do final do século XIX.

32 Nota de Roselyne de Ayala e Paule Braudel: Inúmeras lacunas tornavam ilegível o final do parágrafo. Conseguimos reconstituí-lo graças à obra de Ferdinand Fried, Wende der Weltwirtschaft, 1940, citada por Braudel.

${ }^{33}$ Nota de Roselyne de Ayala e Paule Braudel: Lübeck, onde se localizava o campo de prisioneiros, é perto do rio Weser.

${ }^{34}$ N.T.: A palavra "invariante" estava entre colchetes no original.

${ }^{35}$ Nota de Roselyne de Ayala e Paule Braudel: Tais medidas não figuram no caderno onde lacunas foram organizadas. Registramos as medidas que Fernand Braudel poderia ter indicado segundo as obras científicas que ele dispunha à época.

${ }^{36}$ N.T.: Geógrafa italiana que em 1933 publicou o livro Indagine preventiva sulle recenti variazioni della linea di spiaggia delle coste italiane.

${ }^{37}$ Il Clima sulle Alpi ha mutato in età storica?, 1937. 
${ }^{38}$ N.T.: Destaque nosso.

${ }^{39}$ N.T.: A mais antiga compilação de leis e usos marítimos da Grécia.

${ }^{40}$ N.T.: Os efeitos do Mistral também foram destacados em O Mediterrâneo, p.330-332. Referimo-nos à versão espanhola El Mediterráneo y el mundo mediterráneo en la época de Felipe II, México D.F., Fondo de Cultura Económica, 2002.

${ }^{41}$ N.T.: Para o inverno.

${ }^{42}$ N.T.: Homem de negócios, Siegfried (1875-1959) não pertence ao círculo dos "vidalianos". Interessado por questões políticas e eleitorais, publica, em 1913, o Tableau politique de la France de l'Ouest.

${ }^{43}$ N.T.: Veículos leves e rápidos que serviam aos correios mas só transportavam uma ou duas pessoas.

${ }^{44}$ N.T.: Expressão cunhada pelos Annales para identificar a historiografia tradicional, caracterizada pela memorização de datas, ênfase na biografia de "grandes personagens", na diplomacia, nas batalhas "memoráveis", na documentação escrita e oficial como únicas legítimas de veracidade histórica. Sobre esse assunto, ver o artigo clássico de Lucien Febvre "Uma história que não é a nossa: a história historizante", vertido para o português na coletânea sobre esse historiador organizada por Mota, Carlos Guilherme, Lucien Febvre, São Paulo, Ática, Coleção Grandes Cientistas Sociais, 1978.

${ }^{45}$ N.T.: No livro Fernand Braudel e o Brasil: vivência e brasilianismo (1939-1945), São Paulo, Edusp, 2009, Luís Corrêa Lima aponta o impacto do pensamento de Freyre sobre Braudel. Ele lembra que o primeiro artigo de Braudel publicado nos Annales é uma ampla resenha consagrada à obra do brasileiro (p.155). Braudel também assinaria o prefácio à edição italiana de Casa Grande \& Senzala (p.159).

${ }^{46}$ N.T.: Karl Haushofer (1869-1946) foi um general alemão dedicado à reflexão geopolítica. Professor na Universidade de Berlim, em 1924 fundou o periódico Zeitschrift für Geopolitik (revista de geopolítica). Maiores informações sobre ele, incluindo suas ambíguas ligações com o nazismo, encontram-se em Heske, Henning, Karl Haushofer: his role in German geopolitics and in Nazi politics, Political geography quarterly, v.6, n.2, apr. 1987.

${ }^{47}$ Histoire d'un voyage fait en la terre du Brésil, 1561.

${ }^{48}$ N.T.: Destaque nosso.

${ }^{49}$ N.T.: Ao ser eleito para o Collège de France no ano de 1973, o historiador Emmanuel Le Roy Ladurie intitula sua aula inaugural de L'histoire immobile. Ela foi publicada no ano seguinte nos Annales. Économies, Sociétés, Civilisations, v.29, n.3, p.673-692, 1974.

${ }^{50}$ Nota de Roselyne de Ayala e Paule Braudel: "Durante os dois ou três primeiros anos de seu ensino na Argélia (1923-1932), Fernand Braudel experimentou os caminhos do deserto do Saara, abertos no decorrer de inúmeras viagens - inclusive em camelos".

${ }^{51}$ N.T.: Os que montam em dromedários.

52 N.T.: Longo canto monótono e melancólico.

${ }^{53}$ N.T.: Inútil esclarecer o tom jocoso contido no trecho em questão.

${ }^{54}$ N.T.: Destaque nosso. 